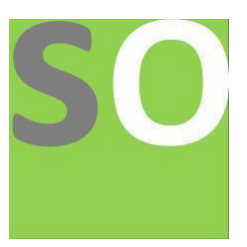

Article title: Interdisciplinary tools to advance agro-food processing research and projects implementation in Egypt Authors: Rashad Hegazy[1]

Affiliations: Agric. Eng. Dept., Faculty of Agriculture, Kafrelsheikh University, Kafrelsheikh 34511, Egypt[1]

Orcid ids: 0000-0003-1266-400X[1]

Contact e-mail: rashad.hegazy@agr.kfs.edu.eg

License information: This work has been published open access under Creative Commons Attribution License http://creativecommons.org/licenses/by/4.0/, which permits unrestricted use, distribution, and reproduction in any medium, provided the original work is properly cited. Conditions, terms of use and publishing policy can be found at https://www.scienceopen.com/.

Preprint statement: This article is a preprint and has not been peer-reviewed, under consideration and submitted to ScienceOpen Preprints for open peer review.

DOI: 10.14293/S2199-1006.1.SOR-.PPSNJVP.v1

Preprint first posted online: 09 January 2021

Keywords: food systems, agro-food processing, interdisciplinarity, sustainability 


\title{
Interdisciplinary tools to advance agro-food processing research and projects implementation in Egypt
}

\author{
Rashad Hegazy \\ Agric. Eng. Dept., Faculty of Agriculture, Kafrelsheikh University, Kafrelsheikh 34511, Egypt. \\ rashad.hegazy@agr.kfs.edu.eg Tel:+21000870898; Fax:+20479102930.
}

\begin{abstract}
Agro-food processing research and projects have several economic development, social equity, and environmental protection goals and can be defined as complex systems linked by dynamic processes and interaction mechanisms. Interdisciplinarity should be the norm, not the exception in agro-food processing projects and research, where individual efforts or to use certain disciplines is no longer a suitable solution. We have to keep our minds open to everything new and to keep them updated regularly and consistent with other mindsets, theories and tools found to advance agro-food processing research and projects. Quality food, natural resources conservation and nutrition security are considered the principal outcomes of agro-food processing research and projects and they determined by decisions and actions taken along different activities. Agro-food processing research and projects is a well-defined theme within food systems with specific millstones and activities' order. We are normally driven by the clear vision of our agro-food processing research and project activities, but in each activity, there are always new and updated applicable concepts to maximize our planned outcomes and impact and to achieve the SDGs which require massive engagement with wide array of actors and disciplines. In this article, we explore some interdisciplinary/multidisciplinary approaches and techniques that can help to design and implement more efficient agro-food processing research and projects. Accordingly, we review general interdisciplinarity concepts and how to use them specifically to extend our current understandings of agro-food processing expertise' dimensions, team working, value chain' actors, and stakeholder relations to achieve the required impact in Egypt.
\end{abstract}

Keywords: food systems; agro-food processing; interdisciplinarity; sustainability

\section{Introduction}

Food systems are defined as the entire range of actors and their interlinked value-adding activities involved in the production, aggregation, processing, distribution, consumption, and disposal of food products [1]. The food system can also be viewed as the sum of all food value chains which make up an important part of the economy in all countries [2].The agro-processing related programmes and projects are focusing on the development of agricultural value chains, food-quality standards, innovations in the processing sector and infrastructure and enabling environment with particular integrating smallholder farmers into value chains. Such activities are largely supported by international non-governmental organizations, with collaboration and funding from intergovernmental agencies and organizations, such as the Food and Agriculture Organization of the United Nations (FAO), the European Bank for Reconstruction and Development, the World Bank, and more [3]. Egypt's agri- 
food system makes up about a quarter of the economy. The food system is rapidly transforming, driven by urbanization and changes in technology and policy. There is a renewed focus on agricultural development in Egypt with continuous efforts for increased public investment to harness the potential of Egypt's agri-food system to accelerate socioeconomic development and to reach national and international development goals [4]. In order to tackle today's agriculture and food security issues, we have to develop smart approaches that improve the relevance and effectiveness of the interaction between different research disciplines. Multiple disciplinarity exposes researchers to their own terminologies, it encourages learning through difference and breaking or affirming paradigms. Multiple disciplinarity challenges researchers to refine their understandings, and forces them to clarify them. It pushes researchers to see that established truths within their disciplines are not the 'only' truth. It encourages out of the- box thinking, it enriches our own writing and contributes to the expansion of each other's viewpoints. Thus we see, on the one hand, the pure 'academic' value of adding new insights into established research programmes and projects, and on the other hand, we see the improvements in our tools and methods for breaking down frontiers to solve societal problems [5]. So, we have to move to the mode of research that integrates knowledge, information, data, techniques, tools, theories, perspectives and concepts from different disciplines, teams and bodies to advance our fundamental understanding or to solve problems or run projects in Egypt.

\section{Methods, Techniques, Tools and Theories}

Various methods, techniques and tools are commonly used to apply and practice the interdisciplinary/multidisciplinary approaches across a range of projects, research and learning materials. This section outlines how interdisciplinary/multidisciplinary tools can approach complex problems in different ways, and how we can adapt some of these techniques and frameworks to offer alternative ways of looking at issues or problems and to identify new, innovative solutions to advance agro-food processing research and projects in Egypt.

\subsection{Agro-food Processing Expertise}

To achieving greater tractability and success in tackling complex societal and environmental problems, e.g. agro-food processing problems, Bammer et al. [6] recommended three expertise' dimensions to examine; first we have to identify the range of expertise required and systematically considering how to include it in teams tackling complex agro-food processing problems; second, locating expertise in research integration and implementation either they are researchers apply specific approaches to tackling agro-food processing problems, or they are researchers develop case-based experience without reference to specific approaches and, by moving from one problem to another, progressively build useful know-that and know-how expertise. The final source of expertise comes from researchers who investigate an element of research integration and implementation and who are not aligned with either of the other researcher' type; third, strengthen expertise in research integration and implementation. Researchers and teams currently duplicate know-that and know-how than to find, build on and improve existing expertise. Identifying expertise and overcoming fragmentation are therefore critical, requiring both an inventory and an organizational framework that promotes accessibility. Both requirements could be achieved by building a dynamic, shared knowledge bank. 
Building a knowledge bank to strengthen expertise in research integration and implementation can provide help in tackling complex societal and environmental problems including agro-food processing problems. Figure (1) illustrate the mutual reinforcement (a virtuous cycle) between a knowledge bank to strengthen expertise in research integration and implementation and success in addressing complex agro-food processing problems.

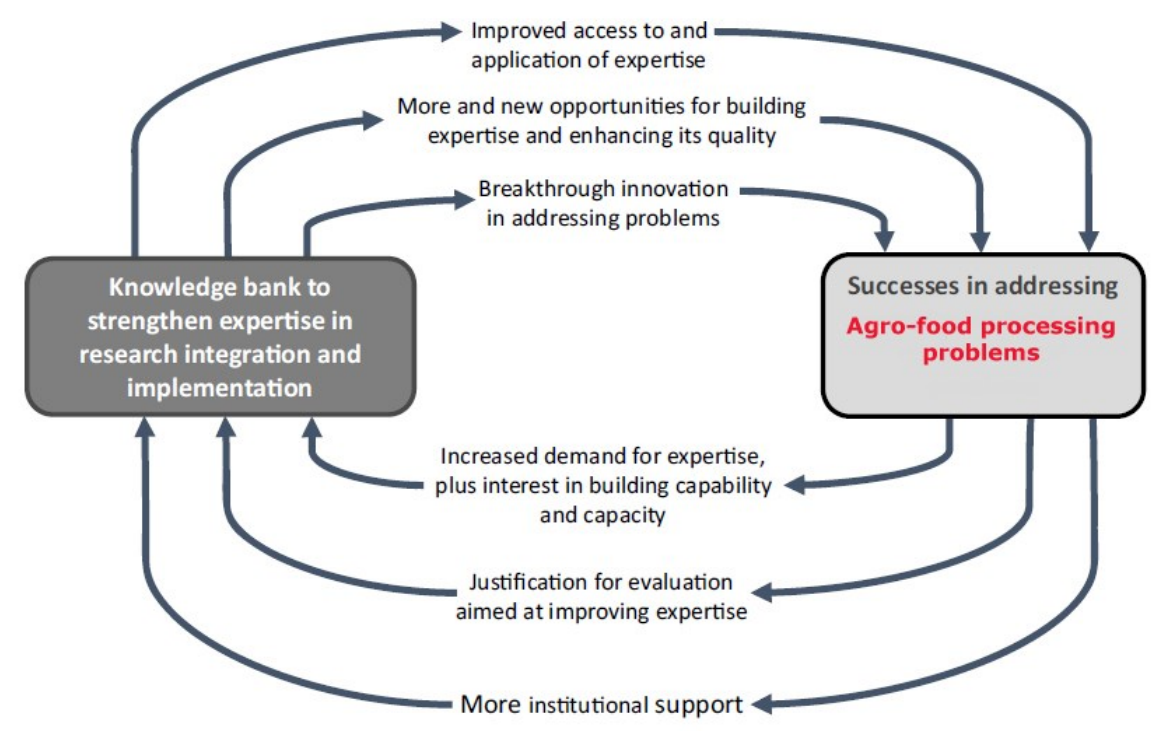

Figure 1. Mutual reinforcement (a virtuous cycle) between a knowledge bank to strengthen expertise in research integration and implementation and success in addressing complex agro-food processing problems, adapted from Bammer et al. [6].

The Academy of Scientific Research \& Technology (ASRT) is a non-profit organization affiliated to the Ministry of Higher Education and Scientific Research, and it has two databases for national and international Egyptian experts and researchers (Figure 2) contributing to development efforts to rebuild the country capitalizing on Egypt's own resources and expertise [7]. The existing databases can be refined to be country-knowledge bank or disciplines-based knowledge banks to strengthen expertise in agro-food processing problems as well as other complex societal and environmental problems. 


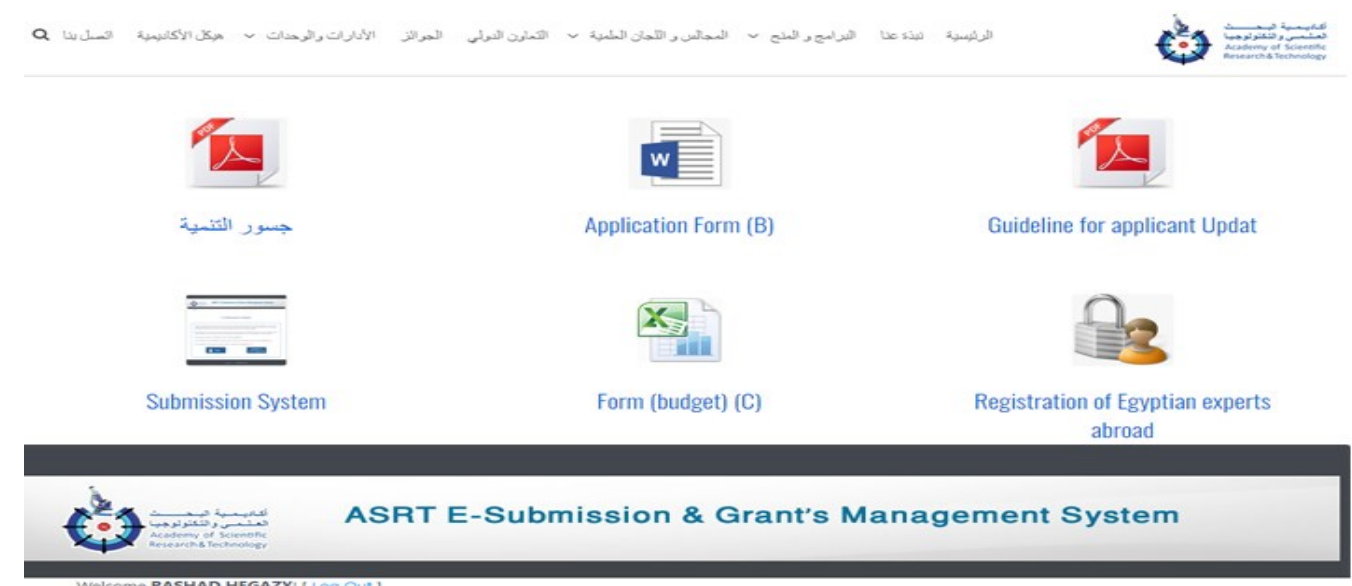

Egyptian Experts

Figure 2. Available databases for national and international Egyptian' experts and researchers

$[7]$.

\subsection{Agro-food Processing Research Themes}

A lot of agro-food processing research themes have been identified through the adoption of ecosystem thinking. Horton et al. [8] identified five inter-connected research domains for agri-food: Land Use and Resource Management; Crop Production and Harvesting; Food Processing, Distribution and Sales; Food Consumption; and Nutrition and Public Health (Figure 3). Clearly they are domains that can be adjusted based on the type and the nature of agro-food processing programmes and projects.

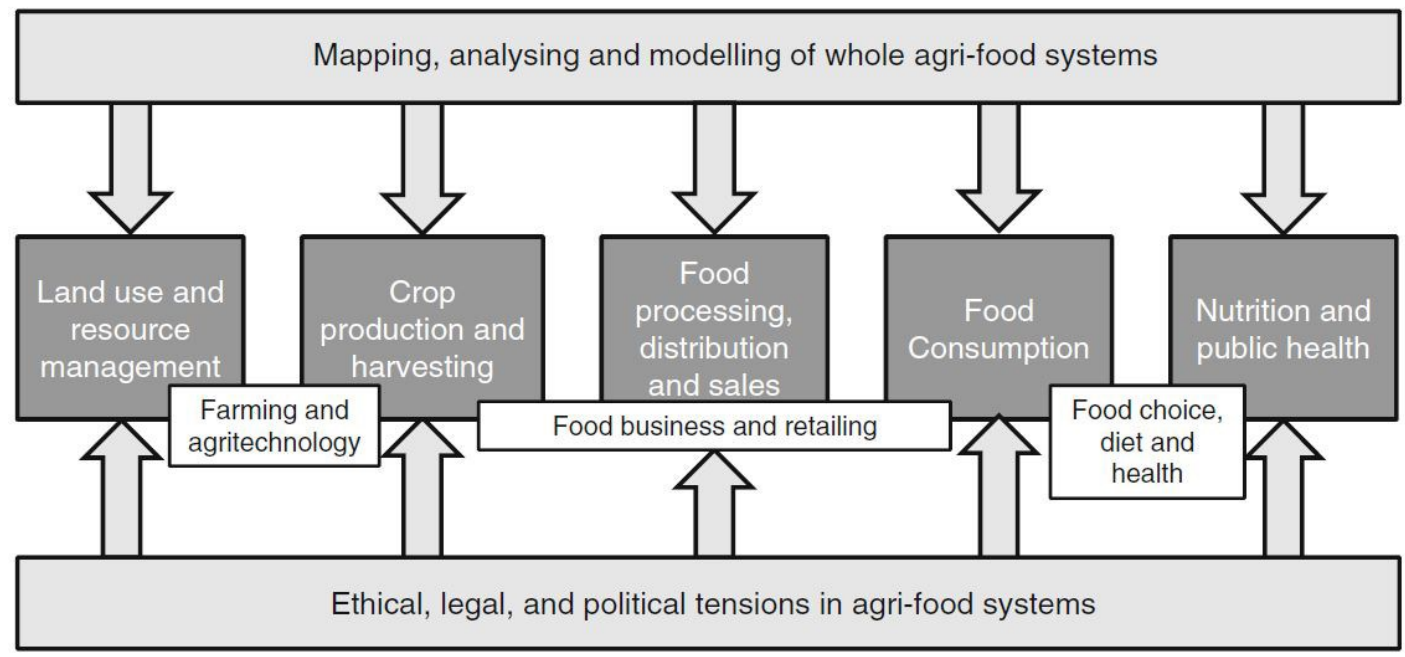

Figure 3. Five core areas of investigation (dark grey), which together address the issues of farming and agri-technology, food business and retailing, and food choice, diet and health (white). 
Two overarching research activities span the core areas (light grey) [8].

Agro-food processing research fields are diverse and multifaceted, while, on the other hand, they point out that more attention should be devoted to the themes of agency in and spatiality/geography of transitions. These inputs should be used to elaborate a research agenda that accommodates the complexity of sustainability transitions processes and their peculiarities and special features in the agro-food system [9]. In order to achieve an effective analysis of agro-food processing research themes, comprehensive qualitative as well as quantitative analysis of problems investigations and required solutions is needed. Also, Understanding the ethical, legal and political issues that shape agri-food systems is also required. And no doubt, the benefits can be maximized if there is well-designed cooperation and alignment between the agricultural sector and other food processing and industries, retail and the water, consumers and end-users, and waste management sectors.

\subsection{Successful Collaborative Team}

Working across boundaries, even within the same scientific organization, can be challenging. This is especially true when an institution's culture values work that is done largely independently, in isolation, and procedures, policies, or processes are not in place to facilitate cross-organizational interactions. Collaborating with others beyond the confines of an organization presents additional challenges. Effective collaboration in the conduct of the research program and projects needs the allocation of additional time and flexibility to uncover important differences when they become relevant and to resolve them. Bennett et al. [10] provided ten top take aways that are easy to apply to Agro-food processing research fields and projects to sustain and strengthen teams' dynamics (Table 1). Currie et al. [11] provided guidance for working together for better outcomes and good practice for interdisciplinary researchers. The guidance note is for researchers and for funders and contains different attributes and support that are required at individual, team and research environment levels.

Table 1. Ten top take aways that are easy to apply to Agro-food processing research fields and projects to sustain and strengthen teams' dynamics [10].

Take Aways Importance

Trust

Vision

Self-Awareness and Emotional Intelligence
It is almost impossible to imagine a successful collaboration without trust. Trust provides the foundation for a team.

A strong and captivating vision attracts people to the team and provides a foundation for achieving team goals. Shared vision provides a focal point around which a highly functioning team can coalesce.

Emotional Intelligence among team members contributes to the effective functioning of research teams. Self-awareness gives people greater control over their own emotional reactions to others, improves the quality of their interactions, and helps build other-awareness. 
Leadership

Mentoring

Team Evolution and Dynamics

Communication

Recognition and

Sharing Success

Conflict and

Disagreement

Navigating and

Leveraging Networks and Systems
Strong collaborative leadership elicits and capitalizes on the team members' strengths and is a critical component of team success. Leadership can be demonstrated by every team member, not just the formal leader ( $\mathrm{s})$.

Mentoring is an indispensable aspect of successful collaboration. A mentor recognizes the strengths of each team member, identifies areas in which newer scientists have the greatest potential to grow, and can help coach people to attain their aspirations.

Research teams form and develop through critical stages to achieve their highest potential (Forming, Storming, Norming, and Performing). A positive team dynamic sustains and further strengthens a research team, enabling it to achieve successful outcomes.

Effective communication within and outside a research team contributes to effective group functioning. It depends on a safe environment where team members can openly share and discuss new scientific ideas and take research into new, previously unconsidered directions as well as ensure that difficult conversations can take place.

Individual contributions should be recognized, reviewed, and rewarded in the context of a collaboration. Recognition and reward of all team members should be done thoughtfully and fairly in the context of the team and the institution.

Conflict can be both a resource and a challenge - a resource because disagreement can expand thinking, add new knowledge to a complex scientific problem, and stimulate new directions for research. A challenge because if it is not handled skillfully, conflict impedes effective team functioning and stifles scientific advancement.

Highly collaborative teams can transcend different organizational structures, extending their reach across and beyond the organization. They often function within the context of multiple and sometimes interconnected systems, and they can help establish strong networks of researchers who together can accomplish more than they could as individuals.

Considering previous important concepts is the key success factor for collaboration between different teams and their themes of sciences in Agro-food processing. However, problem and conflicts may appear due to one or more of problems caused by collaboration such as nature of research, mental models and expectations, values, interests and personality. However, different personal mental models contribute to a common language and to share and refine the general concepts and it is important to 
jointly designing a formal model of a system with different participants is a particularly effective way to discover how far we are speaking same project language and where are the different mental models [12]. So, there is a need to expand our shared understanding related to either different terms or concepts as we experience new concepts and terms every day. There some recommended steps to be sure that we can do understanding each other and to prevent problems to appear later, Easterling [13] suggested five steps for managing diversity to create synergy. All mentioned steps are actually great. From early beginning (in hiring process), where we have to look at who can easily manage the differences and to avoid people who cannot, until we reach collaborative problem-solving step and the feeling of cocreation.

\subsection{Stakeholders Definition}

For successful projects and programmes, active participation of all interested parties in agri-food system development is an important process that can make a significant contribution to effective implementation of the strategy's objectives and achieving sustainable outcomes. European Network for Rural Development [14] clarified the importance of stakeholder involvement and how and why the EU is prepared to invest so much to support the understanding of the true value of stakeholder involvement as active participants in all stages of the policy cycle to better implementation on the ground. Stakeholders are by definition people or organisations that have a "stake" in a matter, by being either involved in (in a position to do something) or affected by it. This covers all the groups concerned with policy delivery from the policy-makers to the (potential) project beneficiaries on the ground. Agro-food processing project may address problems such as poor practices in agricultural production, low productivity \& quality, outdated processing equipment, absence of proper cooling and drying technology, poor access to technical know-how and broken agro-food value chains.

\subsection{Stakeholders Support}

Agri-food processing chains link services and inputs to farm production to food consumption through series of activities. Wide range of stakeholders (input suppliers, farmers, marketers, food processors; consumers, and waste processors) are involved. To support different stakeholders' needs, agro-food processing projects and programmes have to involve many disciplines e.g. agriculture, economy, engineering, environmental sciences, food process, and social science. Number and for each discipline is being determined based on the prioritized area of development and target stakeholders. E.g., projects that target empowering the agricultural products quality may focus more to have agricultural experts as below distribution chart, but with closely aligned activities (Figure 4). It is always good to have framework for scoping about what is central and what is marginal to ensure that critical issues are less likely to be ignored [15]. 


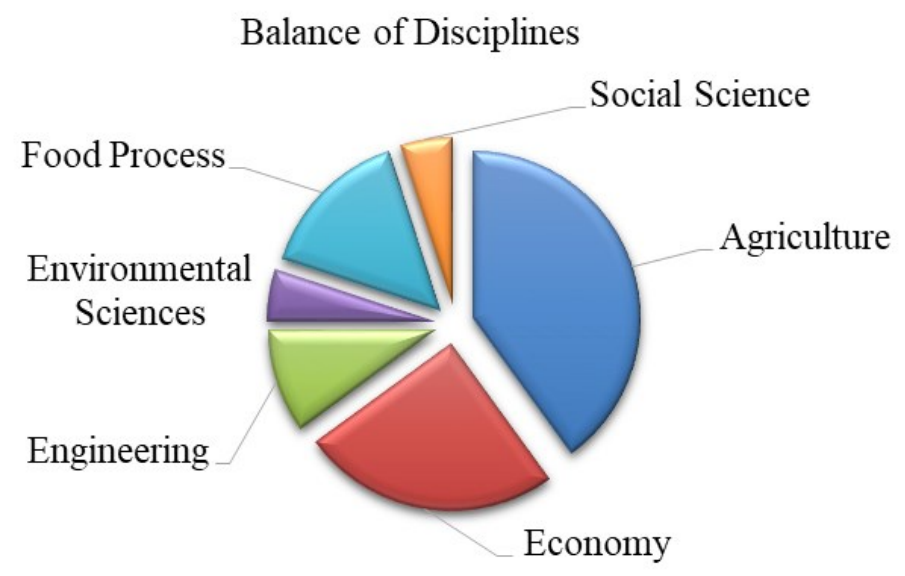

Figure 4. Hypothetical disciplines balance distribution chart.

There are different disciplines related to agri-food systems, and, thus, each discipline must have enough "good" differences that ensure proper support for stakeholders' engagement process, examples of good differences that we can use from each discipline listed in Table 2.

Table 2. Some of the good differences that need to be in different discipline.

Discipline

Agriculture

Economy

Engineering

Environmental

Sciences

Food Sciences

Social Science
Good differences

- Knowledge in conservation agriculture/production/extension.

- Technical skills in best practice/enhancing production trainings.

- Knowledge in farming/marketing business models/evaluations.

- Technical skills in feasibility studies and market analysis/monitoring.

- Knowledge in engineering principles and implementations.

- Technical skills in technology design installation and maintenance.

- Detail-oriented in determining specific technology needs.

- Knowledge in natural resources management.

- Technical skills in agriculture and rural community safe practices.

- Knowledge in quality food and its production chain.

- Technical skills in food technology and safety/control standards.

- Knowledge in rural development and gender balance.

- Technical skills in community training and awareness campaigns. 
- Personal attributes in dealing with individuals and community.

Agro-food processing systems are usually complex networks including significant feedbacks and interactions. Opening the possibility of including iterative processes is always an effective way for better stakeholder engagement and can be practiced from the feedbacks in preparation phase till end of project. E.g., changing project implementation area based on policy maker feedback, changing the priority of crops to include cash crops instead of main cereals based on the participatory appraisal workshop with farmers etc. Because each programme or project has its unique way of implementation, it is good to determine stakeholders' need based by answering "What and whom" questions as below table (Table 3). Also, defining specific separate targets, policy, practices for each stakeholders group in the project as in Table 4, lead to better understanding of stakeholder engagement process.

Table 3. Some of what and whom questions related to stakeholder engagement.

\begin{tabular}{ll}
\hline What to achieve? & Who is intended to benefit? \\
\hline $\begin{array}{l}\text { Appropriate environmentally friendly practices and } \\
\text { technology }\end{array}$ & Farmers, farm owners, labour, and producers \\
$\begin{array}{ll}\text { Agro-processing access affordable finance to adopt } \\
\text { sustainable production practices }\end{array}$ & $\begin{array}{l}\text { MSMEs (Micro, Small \& Medium } \\
\text { Enterprises) }\end{array}$ \\
Better Value-chain partnerships forming between & $\begin{array}{l}\text { Farmers, service providers, associations, } \\
\text { market Leaders and intermediary bodies }\end{array}$ \\
Generate additional income & Farmers, traders, wholesaler, and processors \\
Better and quality food & Consumers \\
\hline
\end{tabular}

Table 4. Example of policy and practices for each stakeholders group.

\begin{tabular}{ll}
\hline Target groups & Change in policy /practice \\
\hline $\begin{array}{l}\text { Stakeholder groups of MSMEs } \\
\text { (Micro, Small \& Medium Enterprises) } \\
\text { involved in agro-food processing and } \\
\text { trade }\end{array}$ & $\begin{array}{l}\text { Change in policy and former linkage between MSMEs and } \\
\text { farmer groups, markets and finance institutions. }\end{array}$ \\
$\begin{array}{l}\text { Farmers groups/associations and } \\
\text { MSMEs }\end{array}$ & $\begin{array}{l}\text { Change to environmentally friendly production and } \\
\text { processing practices. }\end{array}$ \\
Government and policy makers & Change in policy of regulation and certification. \\
Private sector & $\begin{array}{l}\text { Change in practice to reduce transaction costs and improve } \\
\text { market penetration. }\end{array}$ \\
\hline
\end{tabular}




\subsection{Stakeholders Systems Maps}

Stakeholders mapping is an important concepts to consider in stakeholder engagement process [16]. This involves understanding the different problems and to define the required possible solutions and interactions by focusing on the system as a whole rather than focusing on a particular perspective. With different stakeholders involved in project activities, it is better to draw and set the project's range of interventions and connections to show all possible actions and interactions with stakeholders that may occur in the project. Figure 5, illustrate an example of interventions and system map of stakeholder's categories related to agro-food processing.

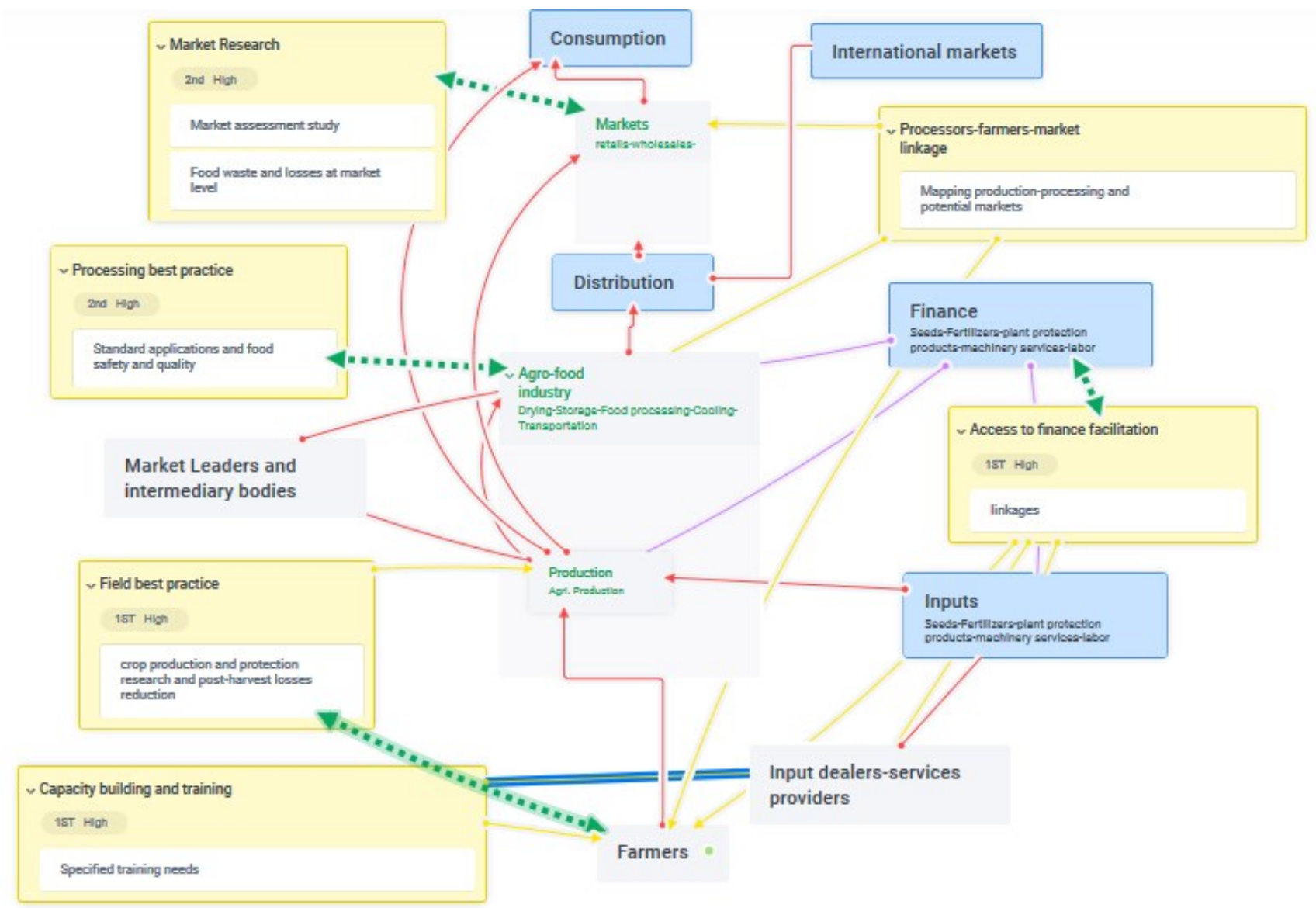

Figure 5. Hypothetical interventions and interactions system map between actors related to agro-food processing stakeholders engagement (red lines refer to different supply chains between stakeholders; green lines refer to two- way interaction between project initiatives and stakeholders; yellow lines refer to different service input operations).

\subsection{Interaction with Stakeholders}

Stakeholders' interaction over the project/programme implementation period assists in developing desired roles and effective strategies to create an environment conducive to effective stakeholder engagement process. Stakeholders' interaction can take different forms starting from 
"informing" or "empowering "as one-way flow of information, to the middle levels of engagement are designed to meet the needs of stakeholders who are 'consulted' and those with whom 'involvement' occurs (e.g. they are more fully engaged, and may also provide resources or data) [17]. Example of interaction methods of two of stakeholders engaged in agro-food processing projects are presented in Table 5.

Table 5. Example of interaction methods of two of stakeholders engaged in agro-food processing projects.

\begin{tabular}{|c|c|c|}
\hline \multirow{2}{*}{ Engagement } & \multicolumn{2}{|c|}{ Stakeholders' group } \\
\hline & Farmers & Private sector \\
\hline Importance & $\begin{array}{l}\text { Farmers contribute to } \\
\text { understanding the problem as they } \\
\text { dealing directly with field } \\
\text { problems and crop needs, they } \\
\text { help in identifying the most } \\
\text { critical problems at production } \\
\text { level, they know what may meet } \\
\text { their needs and expectations more } \\
\text { than anybody, so they help } \\
\text { addressing the required training } \\
\text { and technology for maximizing } \\
\text { the productions and benefits. }\end{array}$ & $\begin{array}{l}\text { Private sector contribute to understanding } \\
\text { the problem as they dealing with the } \\
\text { sustainable solutions and long term } \\
\text { collaboration for win-win situations. Private } \\
\text { sector working with farmers, traders and } \\
\text { processors to collect final product, do the } \\
\text { required distribution linkage and they } \\
\text { understand the market driven concept. }\end{array}$ \\
\hline Interaction & $\begin{array}{l}\text { - Informing them about the project } \\
\text { activities, expected benefits and } \\
\text { what is required from their sides. } \\
\text { - Consulting them regarding the } \\
\text { working locations and training } \\
\text { times. } \\
\text { - Empowering them with best } \\
\text { practice publications, training, } \\
\text { technical support. }\end{array}$ & $\begin{array}{l}\text { - Informing them about the project } \\
\text { activities, expected benefits and the theory } \\
\text { behind the required linkages. } \\
\text { - Consulting them regarding the final } \\
\text { product specifications and consumers } \\
\text { requirement. } \\
\text { - Collaboration in designing some project } \\
\text { activities that lead to better products, } \\
\text { easier and smooth shifting to new } \\
\text { technologies. } \\
\text { - Empowering them with training on latest } \\
\text { standard regulation and processing } \\
\text { guidelines. }\end{array}$ \\
\hline Interaction keep & $\begin{array}{l}\text { - Inform promise by keeping them } \\
\text { informed about any project } \\
\text { updates or any changes that with } \\
\text { relation with them. }\end{array}$ & $\begin{array}{l}\text { - Inform promise by keeping them informed } \\
\text { about any project updates or any changes } \\
\text { that with relation with them. }\end{array}$ \\
\hline
\end{tabular}


- Consult promise by taking - Consult promise by considering their everything they addressed in requirements regarding the final products consideration and plans based on they need and to facilitate their what they need. connections with farms and farmers.

- Empower promise by delivering - Collaborate promise by considering the required training and to private sector needs and target technology provide the needed support on time with respect to their availability and nature. and for-profit activities and recommendations.

- Empower promise by delivering the required training on latest standard regulation and processing guidelines and with better linkages to raw production.

\subsection{Stakeholders' Monitoring and Evaluation Tools}

Formative evaluation for stakeholder engagement process at the start of the project help researchers focus on what needs to be achieved, characteristics of stakeholders, and how to go about achieving objectives, and how to measure success. At the end of each project stage, evaluation monitoring throughout the process provides an opportunity to reflect on the adopted approach and to make changes and improvements where necessary and to support the summative evaluation for outcomes. At the end of project or specific activity, evaluation allows you to consider what has worked well and can therefore be used to help inform future engagement activities. So, to monitor and to evaluate the effectiveness of the engagement process throughout the different engagement stages, stakeholder engagement evaluation table was adapted from Durham et al. [17] and from other evaluation cases studies. However, for each stakeholders group a separate table is needed (Table 6) with additional responses and decisions table to record the answers and keep tracking stakeholder engagement progress.

Table 6. Example of stakeholder engagement evaluation table adapted from Durham et al. [17].

\begin{tabular}{|c|c|c|c|}
\hline & What to know & $\begin{array}{l}\text { Evaluation } \\
\text { methods }\end{array}$ & $\begin{array}{l}\text { Evaluation can be } \\
\text { conducted by }\end{array}$ \\
\hline \multirow[t]{4}{*}{$\begin{array}{l}\text { Planning } \\
\text { Process }\end{array}$} & - Stakeholders' characteristics [18] & $\begin{array}{l}\text { Data evaluation } \\
\text { and analysis }\end{array}$ & $\begin{array}{l}\text { - Local authorities } \\
\text { interviews } \\
\text { - Available data }\end{array}$ \\
\hline & $\begin{array}{l}\text { - Stakeholders' experiences with } \\
\text { previous projects }\end{array}$ & Data analysis & $\begin{array}{l}\text { Local institutions and } \\
\text { authorities data }\end{array}$ \\
\hline & - Time availability of stakeholders & $\begin{array}{l}\text { Feedback } \\
\text { Evaluation }\end{array}$ & $\begin{array}{l}\text { Interviews } \\
\text { stakeholders }\end{array}$ \\
\hline & - Stakeholders' scope for actions & Feedback & Interviews \\
\hline
\end{tabular}




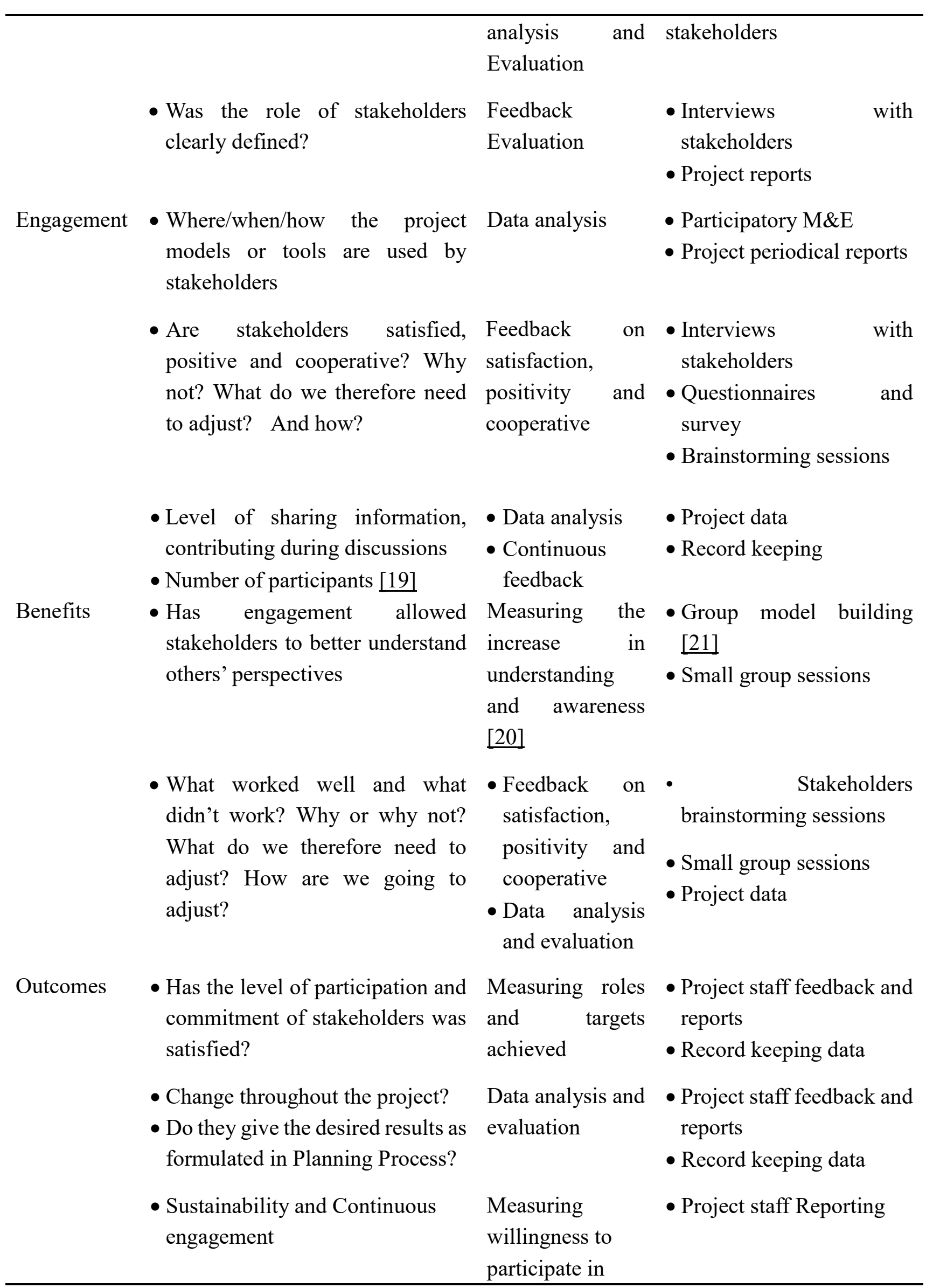


other

projects/activities

in the future
- Interviews with

stakeholders

Table 7, presents hypothetical examples of stakeholder engagement (farmers) evaluation table and possible evaluation methods. Table 8, presents type of decisions that can be taken based on farmers' responses and as an example of stakeholders' responses table in agro-food processing projects and research.

Table 7. Hypothetical example of farmers' engagement evaluation table in agro-food processing projects.

\begin{tabular}{|c|c|c|c|}
\hline & What to know & $\begin{array}{l}\text { Evaluation } \\
\text { methods }\end{array}$ & Evaluation can be conducted by \\
\hline \multirow[t]{5}{*}{ Planning Process } & $\begin{array}{l}\text { - Farmers' } \\
\text { characteristics: } \\
\text { Education level- } \\
\text { Family size-Growing } \\
\text { crops-land size-current } \\
\text { practices }\end{array}$ & $\begin{array}{l}\text { Data evaluation } \\
\text { and analysis }\end{array}$ & $\begin{array}{l}\text { - Extension Department } \\
\text { information } \\
\text { - Data from farmers' } \\
\text { cooperatives }\end{array}$ \\
\hline & $\begin{array}{l}\text { - Farmers' experiences } \\
\text { with national and } \\
\text { international projects }\end{array}$ & Data analysis & $\begin{array}{l}\text { Extension Department } \\
\text { information }\end{array}$ \\
\hline & $\begin{array}{l}\text { - Time availability of } \\
\text { farmers }\end{array}$ & $\begin{array}{l}\text { Feedback } \\
\text { Evaluation }\end{array}$ & Interviews with farmers \\
\hline & $\begin{array}{l}\text { - Farmers' scope for } \\
\text { actions }\end{array}$ & $\begin{array}{l}\text { Feedback } \\
\text { analysis and } \\
\text { Evaluation }\end{array}$ & Interviews with stakeholders \\
\hline & $\begin{array}{l}\text { Was the role of s } \\
\text { farmers clearly } \\
\text { defined? }\end{array}$ & $\begin{array}{l}\text { Feedback } \\
\text { Evaluation }\end{array}$ & $\begin{array}{l}\text { - Interviews with farmers } \\
\text { - project reports }\end{array}$ \\
\hline \multirow[t]{2}{*}{ Engagement } & $\begin{array}{l}\text { - Where/when/how the } \\
\text { project models or tools } \\
\text { are used by farmers? }\end{array}$ & Data analysis & $\begin{array}{l}\text { - Participatory M\&E } \\
\text { - Project periodical reports }\end{array}$ \\
\hline & $\begin{array}{l}\text { Are farmers satisfied, } \\
\text { positive and } \\
\text { cooperative? Why not? } \\
\text { What do we therefore }\end{array}$ & $\begin{array}{l}\text { Feedback on } \\
\text { satisfaction, } \\
\text { positivity and }\end{array}$ & $\begin{array}{l}\text { - Interviews with farmers } \\
\text { - Questionnaires and surveys } \\
\text { - Brainstorming sessions }\end{array}$ \\
\hline
\end{tabular}




\begin{tabular}{|c|c|c|c|}
\hline & $\begin{array}{l}\text { need to adjust? And } \\
\text { how? }\end{array}$ & cooperative & \\
\hline & $\begin{array}{l}\text { - Did farmers share } \\
\text { information, contribute } \\
\text { during discussions? } \\
\text { - How many farmers } \\
\text { participated in each } \\
\text { activity }\end{array}$ & $\begin{array}{l}\text { - Data analysis } \\
\text { - Continuous } \\
\text { feedback }\end{array}$ & $\begin{array}{l}\text { - Project data } \\
\text { - Record keeping }\end{array}$ \\
\hline \multirow[t]{2}{*}{ Benefits } & $\begin{array}{l}\text { - Has engagement } \\
\text { allowed farmers to } \\
\text { better understand } \\
\text { others' stakeholders' } \\
\text { perspectives? }\end{array}$ & $\begin{array}{l}\text { Measuring the } \\
\text { increase in } \\
\text { understanding } \\
\text { and awareness }\end{array}$ & $\begin{array}{l}\text { - Farmers Group model } \\
\text { building } \\
\text { - Farmers Small group sessions }\end{array}$ \\
\hline & $\begin{array}{l}\text { - What worked well } \\
\text { with farmers and what } \\
\text { didn't work? Why or } \\
\text { why not? What do we } \\
\text { therefore need to } \\
\text { adjust? How are we } \\
\text { going to adjust? }\end{array}$ & $\begin{array}{l}\text { - Results } \\
\text { analysis and } \\
\text { Data and } \\
\text { evaluation }\end{array}$ & $\begin{array}{l}\text { - Farmers brainstorming } \\
\text { sessions } \\
\text { - Small farmers' group sessions } \\
\text { - Project data }\end{array}$ \\
\hline \multirow[t]{3}{*}{ Outcomes } & $\begin{array}{l}\text { - Has the level of } \\
\text { participation and } \\
\text { commitment of } \\
\text { farmers was satisfied? }\end{array}$ & $\begin{array}{l}\text { Measuring roles } \\
\text { and targets } \\
\text { achieved }\end{array}$ & $\begin{array}{l}\text { - Project staff feedback and } \\
\text { reports } \\
\text { - Record keeping data }\end{array}$ \\
\hline & $\begin{array}{l}\text { - Did farmers change } \\
\text { their participation } \\
\text { level throughout the } \\
\text { project? } \\
\text { - Do they give the } \\
\text { desired results as } \\
\text { formulated in Planning } \\
\text { Process? }\end{array}$ & $\begin{array}{l}\text { Data analysis and } \\
\text { evaluation }\end{array}$ & $\begin{array}{l}\text { - Project staff feedback and } \\
\text { reports } \\
\text { - Record keeping data }\end{array}$ \\
\hline & $\begin{array}{l}\text { - Are farmers willing to } \\
\text { continue cooperating } \\
\text { in next stages and } \\
\text { projects? }\end{array}$ & $\begin{array}{l}\text { Measuring } \\
\text { willingness to } \\
\text { participate in } \\
\text { other } \\
\text { projects/activities }\end{array}$ & $\begin{array}{l}\text { - Project staff Reporting } \\
\text { - Interviews with farmers }\end{array}$ \\
\hline
\end{tabular}


in the future

Table 8. Hypothetical example of farmers' responses and decisions table in agro-food processing projects.

\begin{tabular}{|c|c|c|c|}
\hline & Information & Decision & Important notes \\
\hline \multirow[t]{5}{*}{ Planning Process } & $\begin{array}{l}\text { - } 92 \% \text { can read and write } \\
\text { - Average family size is } 4 \\
\text { persons } \\
\text { - } 80 \% \text { grow tomatoes and } \\
20 \% \text { cultivate vegetables } \\
\text { - Average land size is } 5 \text { Fed. } \\
\text { with traditional practices }\end{array}$ & $\begin{array}{l}\text { Stakeholders meet the } \\
\text { project requirements }\end{array}$ & $\begin{array}{l}\text { The project will } \\
\text { prioritize the tomato } \\
\text { 'growers only }\end{array}$ \\
\hline & $\begin{array}{l}\text { - No experiences with } \\
\text { national and international } \\
\text { projects }\end{array}$ & $\begin{array}{l}\text { More efforts are needed in } \\
\text { project orientation }\end{array}$ & $\begin{array}{l}\text { Clear understanding } \\
\text { is essential e.g. no } \\
\text { cash or seed support } \\
\text { only technical } \\
\text { assistant }\end{array}$ \\
\hline & - Time availability of farmers & Available & $\begin{array}{l}\text { Consider peak } \\
\text { season activities }\end{array}$ \\
\hline & - Farmers' scope for actions & $\begin{array}{l}\text { They are motivated with } \\
\text { clear understanding of the } \\
\text { limitations }\end{array}$ & $\begin{array}{l}\text { Keep informing } \\
\text { them about scope } \\
\text { of the project }\end{array}$ \\
\hline & $\begin{array}{l}\text { Was the role of s farmers } \\
\text { clearly defined? }\end{array}$ & yes & - \\
\hline \multirow[t]{2}{*}{ Engagement } & $\begin{array}{l}\text { - Where/when/how the } \\
\text { project models or tools are } \\
\text { used by farmers? }\end{array}$ & $\begin{array}{l}\text { Working location, areas } \\
\text { and time of activities are } \\
\text { set with them and they } \\
\text { accepted }\end{array}$ & $\begin{array}{l}\text { Early notice with } \\
\text { proper arrangement } \\
\text { with field team }\end{array}$ \\
\hline & $\begin{array}{l}\text { Are farmers satisfied, } \\
\text { positive and cooperative? } \\
\text { Why not? What do we } \\
\text { therefore need to adjust? } \\
\text { And how? }\end{array}$ & Yes & - \\
\hline
\end{tabular}




\begin{tabular}{|c|c|c|c|}
\hline & $\begin{array}{l}\text { - Did farmers share } \\
\text { information, contribute } \\
\text { during discussions? } \\
\text { - How many farmers } \\
\text { participated in each activity }\end{array}$ & $\begin{array}{l}\text { - Yes } \\
\text { - Participation percentage } \\
\text { in meetings and field } \\
\text { days is } 80 \% \text { with } 70: 30 \\
\text { gender imbalance } \\
\text { percentage }\end{array}$ & $\begin{array}{l}\text { Need to achieve } \\
\text { higher percentages } \\
\text { with gender balance }\end{array}$ \\
\hline \multirow[t]{2}{*}{ Benefits } & $\begin{array}{l}\text { - Has engagement allowed } \\
\text { farmers to better understand } \\
\text { others' stakeholders' } \\
\text { perspectives? }\end{array}$ & Yes & - \\
\hline & $\begin{array}{l}\text { - What worked well with } \\
\text { farmers and what didn't } \\
\text { work? Why or why not? } \\
\text { What do we therefore need } \\
\text { to adjust? How are we going } \\
\text { to adjust? }\end{array}$ & $\begin{array}{l}\text { - Interaction (informing } \\
\text { and consulting ) is going } \\
\text { on well } \\
\text { - Empowering need more } \\
\text { efforts to concentrate on } \\
\text { assigned technical data } \\
\text { only }\end{array}$ & $\begin{array}{l}\text { Explain clearly that } \\
\text { the project provide } \\
\text { production technical } \\
\text { assistant but no } \\
\text { relation to water and } \\
\text { electricity issues }\end{array}$ \\
\hline \multirow[t]{3}{*}{ Outcomes } & $\begin{array}{l}\text { - Has the level of } \\
\text { participation and } \\
\text { commitment of farmers was } \\
\text { satisfied? }\end{array}$ & $\begin{array}{l}80 \% \text { of engagement } \\
\text { achieved }\end{array}$ & $\begin{array}{l}\text { To consider the } \\
\text { reasons and } \\
\text { solutions for coming } \\
\text { stage }\end{array}$ \\
\hline & $\begin{array}{l}\text { Did farmers change their } \\
\text { participation level } \\
\text { throughout the project? } \\
\text { - Do they give the desired } \\
\text { results as formulated in } \\
\text { Planning Process? }\end{array}$ & $\begin{array}{l}\text { - No, almost fixed } \\
\text { - Yes }\end{array}$ & - \\
\hline & $\begin{array}{l}\text { - Are farmers willing to } \\
\text { continue cooperating in next } \\
\text { stages and projects }\end{array}$ & Yes & $\begin{array}{l}\text { Data bases and } \\
\text { project data to be } \\
\text { cleaned and to } \\
\text { save them }\end{array}$ \\
\hline
\end{tabular}

In general, agro-food processing projects has many stakeholders groups involved in its implementation. There is clear monitoring and evaluation tools and methods for project outputs and outcomes, but, there is no a separate simple way of evaluating and monitoring stakeholder engagement process. Adapting stakeholder monitoring and evaluation formative evaluation tool is very acceptable and logic for effective stakeholders' engagement process in project stages. Figure 6, shows a hypothetical example of utilizing and use stakeholder engagement evaluation tool in different project 
stages adapted from Thoradeniya and Maheshwari [22].

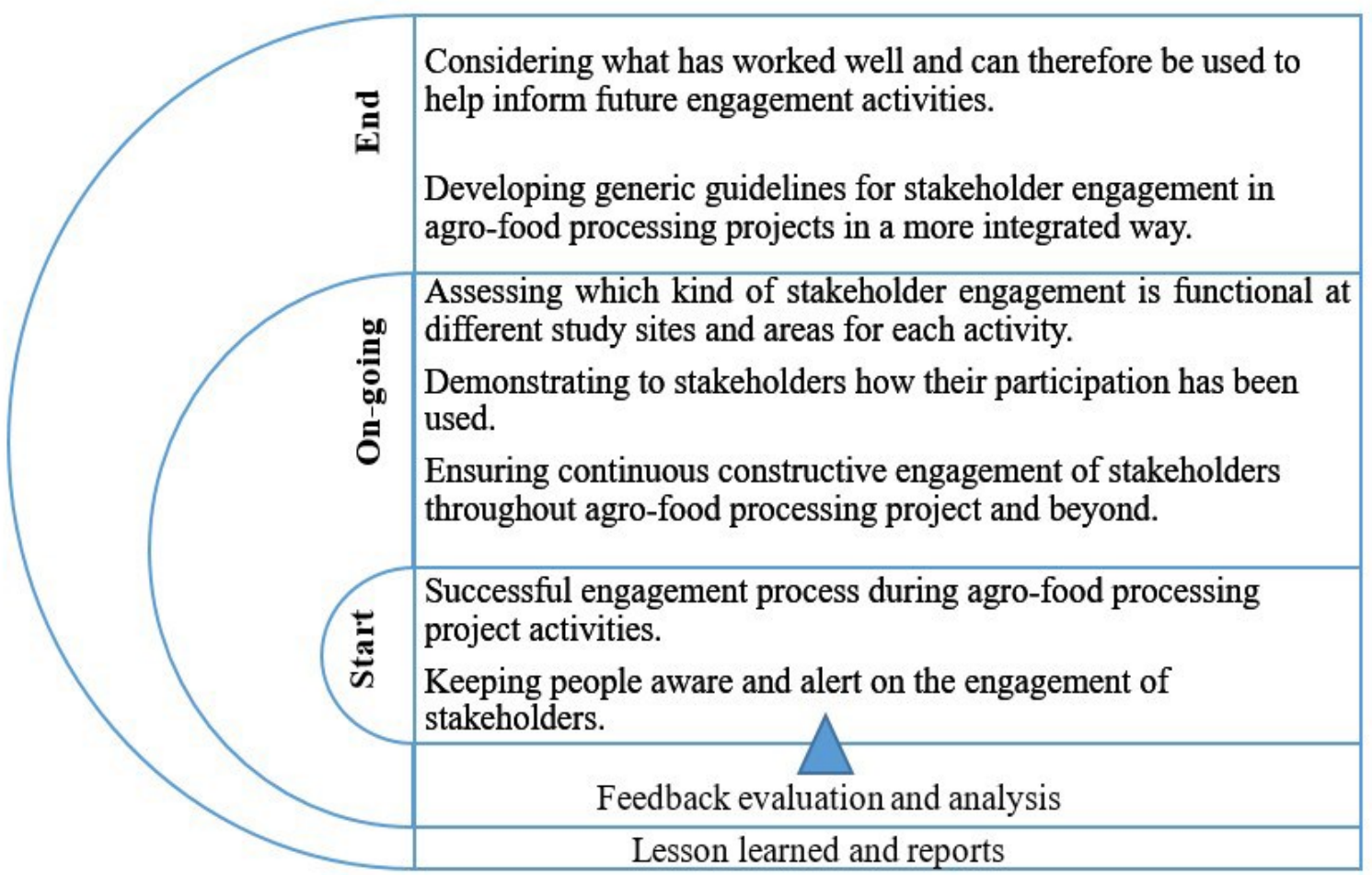

Figure 6. Utilizing and use stakeholder engagement evaluation tool in different project stages adapted from Thoradeniya and Maheshwari [22].

\subsection{Co-Innovation as a Research Approach for Agro-Food Processing}

Co-innovation is the process of jointly developing new or different solutions to an agricultural problem through multi-participant research processes (and keeping these processes alive through-out the research) [23]. Co-innovation can be effective for complex challenges-involving interactions amongst multiple stakeholders, viewpoints, perceptions, practices and interests across programmes, sectors and national systems. Approaches to challenges in the primary sector have tended to be linear, where tools and outputs are developed by a few, mostly scientists/researchers, and then extended to stakeholders [24]. Agro-food processing is a complex research problem with hard-to-solve technical, social, cultural and economic/market challenges. There are many different players with a stake in the research problem and solution. That is why, co-innovation is one of most suited approaches for dealing with agro-food processing research problems. Boyce et al. [23] cleared proposed that one way to think about co-innovation as a research approach is to work with others from first stage to design the research issues and outcomes with partners and stakeholders, and in later stages to develop the details of the research process. And, once the research is completed, design together to share the results and focus on how these findings could be implemented. There are five principles of co-innovation that can be applied to research proposals (applicable to Agro-food processing research proposals), these five principles are; involve partners and stakeholders; take a problem focus; assemble the right team; front up early and often; and use the action learning cycle: Plan-Do-Observe-Reflect (Figure 7) [23]. 


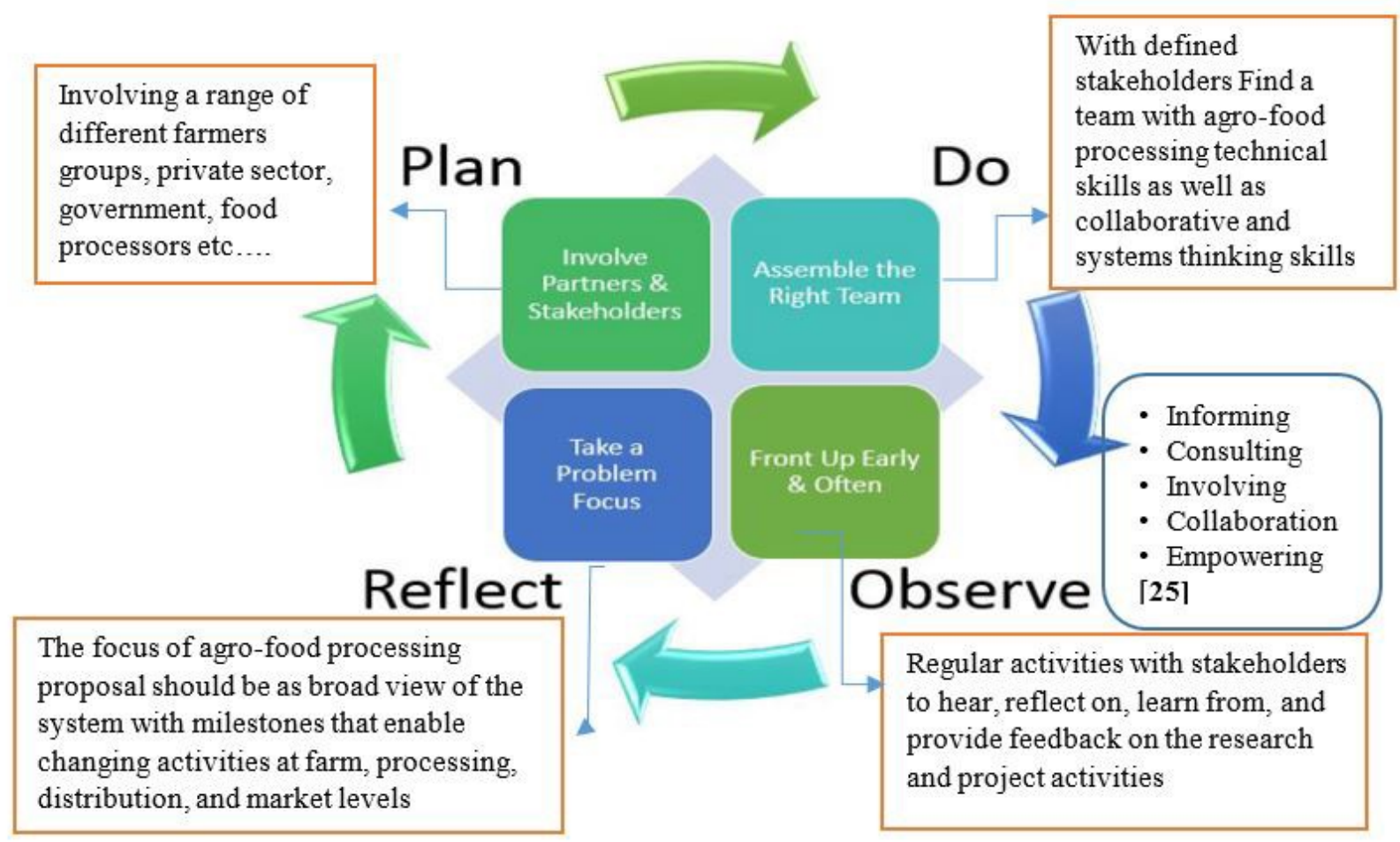

Figure 7. Five principles of co-innovation that can be applied to Agro-food processing research proposals and projects adapted from Boyce et al. [23].

It has highlighted that a different research mindset to stakeholder engagement is required and multiple ways to engage stakeholders are needed (inform, consult, involve, collaborate, and empower) [25]. The Integration and Implementation Sciences (i2S) framework is introduced as a way to systematically take into account multiple stakeholders with multiple relevant inputs. In addition, one specific tool, the research-relevant modified International Association for Public Participation (IAP2) spectrum, is described as a way of exploring stakeholder engagement (Figure 8). 


\begin{tabular}{|c|c|c|c|c|c|}
\hline & \multicolumn{5}{|c|}{ INCREASING STAKEHOLDER INFLUENCE ON THE RESEARCH } \\
\hline & INFORM & CONSULT & INVOLVE & COLLABORATE & EMPOWER \\
\hline 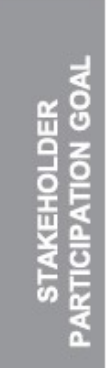 & $\begin{array}{l}\text { Researchers } \\
\text { provide } \\
\text { stakeholders with } \\
\text { balanced and } \\
\text { objective } \\
\text { information to } \\
\text { assist them in } \\
\text { understanding the } \\
\text { research process. }\end{array}$ & $\begin{array}{l}\text { Researchers obtain } \\
\text { stakeholder } \\
\text { feedback on the } \\
\text { research process. }\end{array}$ & $\begin{array}{l}\text { Researchers work } \\
\text { directly with } \\
\text { stakeholders to } \\
\text { ensure that } \\
\text { stakeholder } \\
\text { concerns and } \\
\text { aspirations are } \\
\text { consistently } \\
\text { understood and } \\
\text { considered in the } \\
\text { research process. }\end{array}$ & $\begin{array}{l}\text { Researchers partner } \\
\text { with stakeholders for } \\
\text { salient aspects of the } \\
\text { research process. }\end{array}$ & $\begin{array}{l}\text { Researchers assist } \\
\text { stakeholders in } \\
\text { conducting their } \\
\text { own research. }\end{array}$ \\
\hline 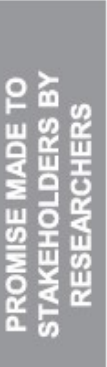 & $\begin{array}{l}\text { We will keep you } \\
\text { informed. }\end{array}$ & $\begin{array}{l}\text { We will keep you } \\
\text { informed, listen to } \\
\text { and acknowledge } \\
\text { your concerns and } \\
\text { aspirations and } \\
\text { provide feedback } \\
\text { on how your input } \\
\text { influenced the } \\
\text { research process. }\end{array}$ & $\begin{array}{l}\text { We will work with } \\
\text { you to ensure your } \\
\text { concerns and } \\
\text { aspirations are } \\
\text { directly reflected in } \\
\text { the research } \\
\text { process and we will } \\
\text { provide feedback } \\
\text { on how your input } \\
\text { influenced the } \\
\text { research. }\end{array}$ & $\begin{array}{l}\text { We will look to you } \\
\text { for advice and } \\
\text { innovation in } \\
\text { designing and } \\
\text { conducting the } \\
\text { research process and } \\
\text { incorporate your } \\
\text { advice and } \\
\text { recommendations to } \\
\text { the maximum extent } \\
\text { possible. }\end{array}$ & $\begin{array}{l}\text { We will provide } \\
\text { advice and } \\
\text { assistance as } \\
\text { requested in line } \\
\text { with your decisions } \\
\text { for designing and } \\
\text { conducting your } \\
\text { research, as well as } \\
\text { for implementing } \\
\text { the findings. }\end{array}$ \\
\hline
\end{tabular}

Figure 8. Research-relevant modified IAP2 spectrum. This spectrum for stakeholder participation in research is adapted from the International Association for Public Participation (IAP2) spectrum of public participation in decision making [25].

Saragih and Tan [26] investigated the previous theoretical and empirical studies regarding the current philosophical understandings of co-innovation in business and economics contexts, and subsequently suggested a theoretical framework that exhibits the analytical pillars and the possible outputs of this notion in practice through various case studies. They proposed five principal elements within the idea of co-innovation were collaboration, coordination, co-creation, convergence and complementary (similar to Boyce et al. [23]). The co-innovation conceptual framework they proposed can be adapted to consider the nature of Agro-food processing research and projects and the outputs can be new services for beneficiaries, methodologies, value chains and different business models for prompting new best practices and better products as in Figure 9. 


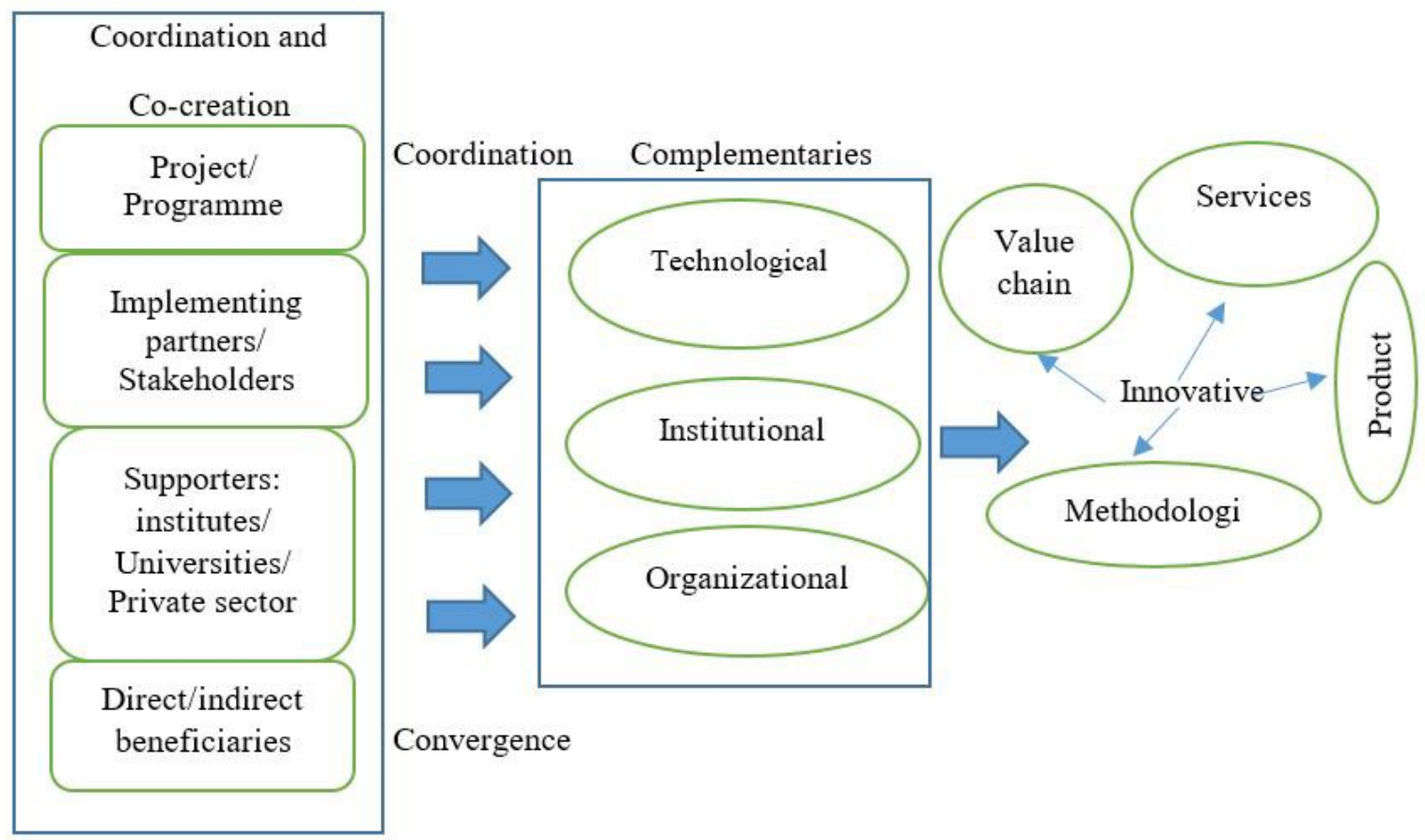

Figure 9. Potential conceptual framework for agro-food processing research and projects coinnovation, adapted from Saragih and Tan [26].

\subsection{Scaling the Impact}

Agricultural programmes are an instrument to achieve positive impact on local communities. Today's development financial institutions (DFIs) are looking for financial results but also aim to achieve economic, social and environmental impacts. Efforts to make agricultural research for development (AR4D) more outcome-based in demonstrable ways has influenced experimentation with various approaches. It is in this context that the theory of change (ToC) comes into play to help designing more effective programs. The ToC has key elements of the outcome-based approaches, such as a focus on influencing policy, but is considered more flexible. The concept started to gain more acceptance because of donor requirements, and it increasingly been applied to design proposals and evaluate the impact of development projects In its 2008 World development report, the World Bank insisted on the need to invest in agriculture and agro-industry to boost growth and reduce poverty with considerable scope to up-scaling Agro-food processing initiatives [27]. Amplifying the impact of sustainability initiatives to foster transformations in urban and rural contexts, has received increasing attention in resilience, social innovation, and sustainability transitions research, to increase the impact of such initiatives. However, there are many interventions that are effective at a small scale, so that getting them implemented more widely is critical to achieving improved agricultural programs and we don't have to keep reinventing the same interventions at a small scale. Lam et al. [28] have identified eight amplification processes and grouped them into three categories: amplifying within, out, and beyond. Considering one or more of the eight identified amplification processes may lead to increase the impact of sustainable initiatives in urban and rural contexts. The developed integrative typology of the defined eight processes is presented in Figure 10. Table 9, gives examples about illustrating the 
amplification processes with describing what the impact is and how it is amplified in Agro-food processing research and projects.

\section{TYPOLOGY OF AMPLIFICATION PROCESSES}

\begin{tabular}{|c|c|c|c|}
\hline & Categories & EIght generic & $\begin{array}{l}\text { ypes of amplifi } \\
\text { ses }\end{array}$ \\
\hline $\begin{array}{l}\text { Amplifying } \\
\text { within } \\
\text { an initiative }\end{array}$ & $\begin{array}{l}\text { Impact? and how it is amplified? } \\
\text { Reduction of crop waste and } \\
\text { loss at market } \\
\text { Access to finance }\end{array}$ & STABILIZING & SPEEDING UP \\
\hline $\begin{array}{l}\text { Amplifying } \\
\text { out } \\
\text { an initiative }\end{array}$ & $\begin{array}{c}\text { Access to market prices } \\
\text { Wholesaler-farmers-traders } \\
\text { value chain linkage } \\
\text { Moving from adapted surface irri- } \\
\text { gation in delta region in Egypt to } \\
\text { modern irrigation systems } \\
\text { Support SMEs to adapt } \\
\text { national and interna- } \\
\text { tional standard }\end{array}$ & $\begin{array}{l}\text { similar context } \\
\text { TRANSFERRING } \\
\text { similar context }\end{array}$ & dissimilar context \\
\hline $\begin{array}{l}\text { Amplifying } \\
\text { beyond } \\
\text { an initiative }\end{array}$ & $\begin{array}{l}\text { Social protecting during } \\
\text { crisis }\end{array}$ & UP & SCALING DEEP \\
\hline
\end{tabular}

Figure 10. Developed Illustration of the eight amplification processes grouped into three categories, adapted from Lam et al. [28].

Table 9. Hypothetical examples about illustrating the amplification processes with describing what the impact is and how it is amplified in Agro-food processing research and projects adapted from Lam et al. [28].

Amplification

processes Example

Stabilizing Traders associations

Speeding up Financial support to small-scale food processors
What is the impact and how it is amplified?

Impact: reduction of crop waste and loss at market level.

Amplification: Stabilizing impact through Getting support from local NGO to stablishing small-scale tomato processing unit with cooperation with traders near markets

Impact: access to finance and easy transaction

Amplification: Speeding up impact through restructuring processes to provide capital faster after submitting 


\begin{tabular}{|c|c|c|}
\hline & & proposals \\
\hline \multirow{2}{*}{ Growing } & \multirow{2}{*}{ Farmers } & Impact: access to market prices \\
\hline & & $\begin{array}{l}\text { Amplification: Speeding up impact through mobile } \\
\text { application with daily market prices }\end{array}$ \\
\hline \multirow{2}{*}{ Replicating } & \multirow{2}{*}{ Wholesalers } & Impact: wholesaler-farmers-traders value chain linkage \\
\hline & & $\begin{array}{l}\text { Amplification: Replicating local chapters to different } \\
\text { regions }\end{array}$ \\
\hline \multirow[t]{2}{*}{ Transferring } & \multirow[t]{2}{*}{$\begin{array}{l}\text { Farmers' irrigation } \\
\text { water associations }\end{array}$} & $\begin{array}{l}\text { Impact: moving from adapted surface irrigation in delta } \\
\text { region in Egypt to modern irrigation systems adapted by } \\
\text { new reclaimed area. }\end{array}$ \\
\hline & & $\begin{array}{l}\text { Amplification: immediate government subsidies for new } \\
\text { system installation }\end{array}$ \\
\hline \multirow[t]{2}{*}{ Spreading } & \multirow[t]{2}{*}{ MSMEs } & $\begin{array}{l}\text { Impact: support MSMEs to adapt national and international } \\
\text { standard }\end{array}$ \\
\hline & & $\begin{array}{l}\text { Amplification: Spreading of key principles and different } \\
\text { standards }\end{array}$ \\
\hline \multirow{2}{*}{ Scaling up } & \multirow{2}{*}{$\begin{array}{l}\text { National crop } \\
\text { insurance system }\end{array}$} & Impact: social protecting during crisis for farmers \\
\hline & & Amplification: national fixed crop insurance system \\
\hline \multirow{2}{*}{ Scaling dee } & \multirow{2}{*}{$\begin{array}{l}\text { Social inclusion in } \\
\text { agri-based } \\
\text { communities }\end{array}$} & Impact: Providing services in communities \\
\hline & & $\begin{array}{l}\text { Amplification: Changing values through increasing social } \\
\text { inclusion in communities by promoting reciprocal altruism. }\end{array}$ \\
\hline
\end{tabular}

To enhance the impact of research, policy and practice and to create long-term relationships with two-way dialogue between researchers and stakeholders in order to ensure effective co-generation of new knowledge, Reed et al. [29] developed five principles that are based on an empirical analysis of interviews with researchers and stakeholders across 13 research projects (Figure 11). These principles (design, represent, engage, impact, reflect and sustain) are highlighting the importance and methods of knowledge exchange stakeholder engagement, collaboration and research implementation. These principles are usually used to describe the research that is conducted before amplification, but they can also be applied to make amplification more effective. 


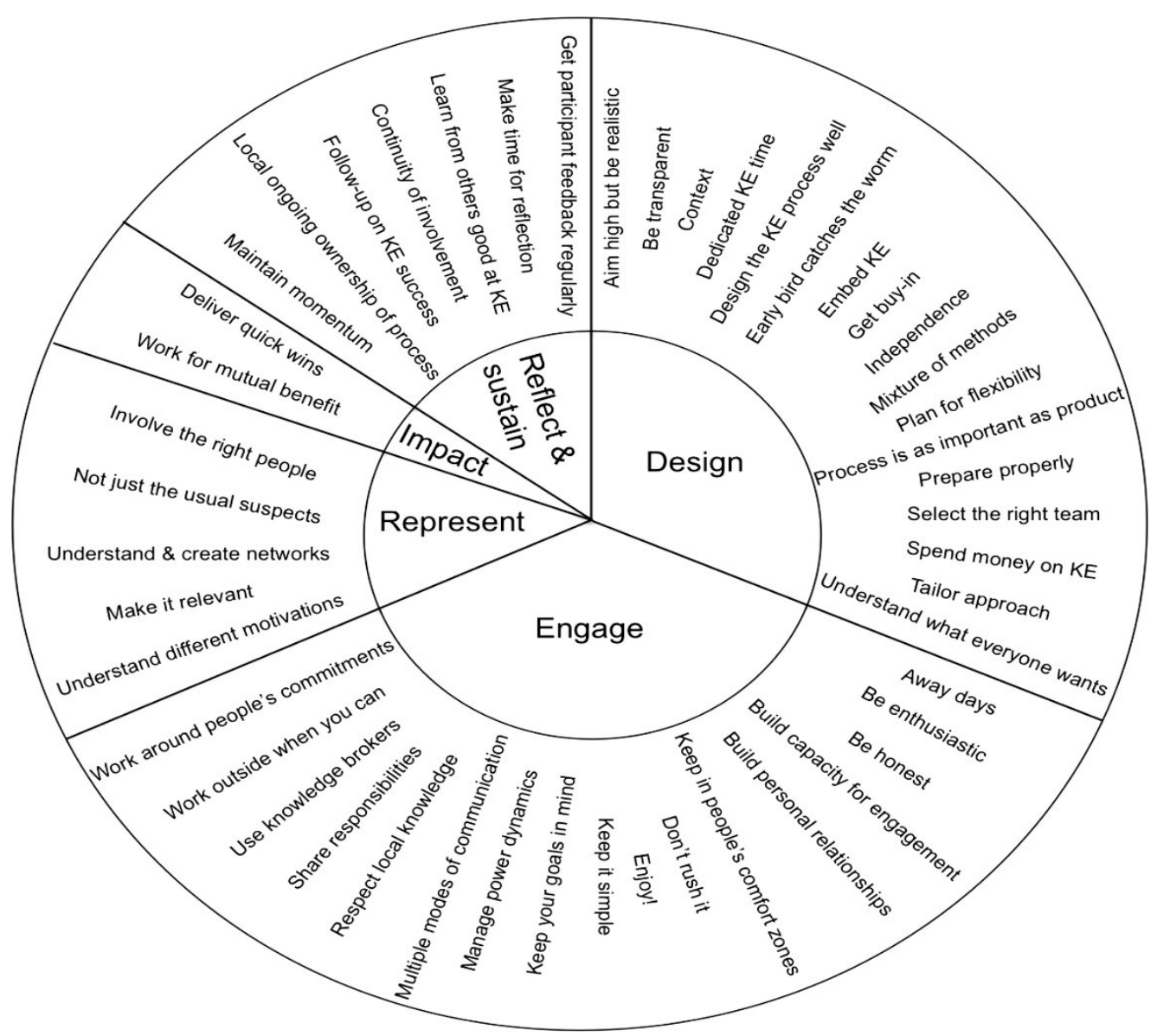

Figure 11. Five principles that enhance the impact of research, policy and practice developed by Reed et al. [29].

\subsection{Impact Integration and Integrative Tasks}

Poverty reduction will be achieved by targeting the vertical and horizontal integration of smallholder farmers, and small-scale processing industries in the value-chains [30]. Agro-food processing projects and research are part of the global/Egyptian food systems that faces challenges related to food security, climate change, loss of biodiversity, and decrease of suitable land and water resources. Understanding climate change risks to food production is an important part of addressing these challenges. It requires consideration of complex interactions of bio-physical, economic, political and social factors at various scales. Integrated assessments and modelling (IAM) provides a multilevel and interdisciplinary framework that brings together and synthesizes scientific knowledge from relevant disciplines. Hamilton et al. [31] highlighted ten dimensions of integration that are of particular interest in integrated assessment and modelling (IAM) which focuses on environmental-related sciences. For successful assessment or decision making purposes, all salient dimensions of integrated modelling must be addressed with respect to its purpose and context. The key dimensions include: issues of concern; management options and governance arrangements; stakeholders; natural systems; human systems; spatial scales; temporal scales; disciplines; methods, models, tools and data; and sources and types of uncertainty. More details about the ten dimensions are presented in Table 10. 
Table 10. Details of the ten dimensions of integration in integrated assessment and modelling (IAM) [31].

\begin{tabular}{|c|c|}
\hline Dimension & Explanation \\
\hline Issues of concern & $\begin{array}{l}\text { Research teams/stakeholders have different views about the issue and how it } \\
\text { may be managed. Holistic treatment of issues is important to minimize } \\
\text { conflicts, and ensure a management option implemented to address one issue } \\
\text { does not cause unacceptable problems in other parts of the system. }\end{array}$ \\
\hline Governance setting & $\begin{array}{l}\text { Governance may include public or private action; by an individual, an } \\
\text { organisation or the government; in an operational, tactical or strategic context; } \\
\text { and across or within institutional, sectorial and geographical boundaries. }\end{array}$ \\
\hline Stakeholders & $\begin{array}{l}\text { Stakeholders can be individuals or interest groups related to the sources of the } \\
\text { problem }\end{array}$ \\
\hline Natural setting & $\begin{array}{l}\text { This dimension relates to the integration of components of the biophysical } \\
\text { systems of interest (climate, land, water, atmospheric and/or ecological } \\
\text { systems). }\end{array}$ \\
\hline Spatial scale & $\begin{array}{l}\text { There are different spatial scales at which the various important processes of } \\
\text { a system occur or can be represented by data or a model. }\end{array}$ \\
\hline Time scale & $\begin{array}{l}\text { Temporal scales of processes are often related to their spatial scale, and many } \\
\text { of the challenges and approaches to deal with the spatial scales are relevant to } \\
\text { those for temporal issues }\end{array}$ \\
\hline Disciplines & $\begin{array}{l}\text { Integration of knowledge and competencies from a broad range of paradigms } \\
\text { (e.g. positivist, interpretive) and disciplines (e.g. ecology, economics, } \\
\text { engineering, etc....). }\end{array}$ \\
\hline $\begin{array}{l}\text { Methods, models, } \\
\text { other tools and data }\end{array}$ & $\begin{array}{l}\text { This dimension concerns the technical integration of different methods, } \\
\text { models, other tools and data from various disciplines and/ or representing } \\
\text { different processes or perspectives }\end{array}$ \\
\hline Uncertainty & $\begin{array}{l}\text { Uncertainty is widely accepted to be pervasive in any attempt to manage and } \\
\text { understand environmental problems. Uncertainty can be interpreted in } \\
\text { different ways depending on the discipline, and the context of application }\end{array}$ \\
\hline
\end{tabular}

After getting familiar enough with above dimensions, the next step is to integrate these dimensions to fits in the four main phases in the integrated assessment process (Table 11): scoping, problem framing and formulation, assessing options, and communicating findings. Participatory processes and modelling tools can be used to achieve integration in such complex environmental and 
food systems problems.

Table 11. Example of integrating two dimensions (issues of concern and uncertainty) to fits in the four main phases in the integrated assessment process.

\begin{tabular}{|c|c|c|c|c|}
\hline Dimension & Scoping & $\begin{array}{l}\text { Problem framing } \\
\text { and formulation }\end{array}$ & $\begin{array}{l}\text { Analysis and assessment } \\
\text { of options }\end{array}$ & $\begin{array}{l}\text { Communication } \\
\text { of findings }\end{array}$ \\
\hline $\begin{array}{l}\text { Issues of } \\
\text { concern }\end{array}$ & $\begin{array}{l}\text { Identifying } \\
\text { important } \\
\text { issues /rapid } \\
\text { appraisal, } \\
\text { stakeholder } \\
\text { workshops, } \\
\text { focus groups }\end{array}$ & $\begin{array}{l}\text { Including relevant } \\
\text { indicators to use as } \\
\text { performance } \\
\text { criteria/soft systems } \\
\text { methodologies, } \\
\text { stakeholder } \\
\text { workshops, focus } \\
\text { groups, expert } \\
\text { elicitation }\end{array}$ & $\begin{array}{l}\text { Evaluating alternatives } \\
\text { based on how it is } \\
\text { predicted to affect the } \\
\text { performance measures / } \\
\text { Multiple Criteria } \\
\text { Decision Analysis } \\
\text { (MCDA), analytic } \\
\text { hierarchy process, multi- } \\
\text { objective optimisation, } \\
\text { trade-off analysis }\end{array}$ & $\begin{array}{l}\text { Target } \\
\text { communication } \\
\text { towards issues } \\
\text { of concern }\end{array}$ \\
\hline Uncertainty & $\begin{array}{l}\text { Considering } \\
\text { alternative } \\
\text { boundaries of } \\
\text { scope }\end{array}$ & $\begin{array}{l}\text { Considering } \\
\text { alternative problem } \\
\text { formulations }\end{array}$ & $\begin{array}{l}\text { Considering alternative } \\
\text { model instances } \\
\text { /uncertainty } \\
\text { quantification, hypothesis } \\
\text { testing, (pseudo) Monte } \\
\text { Carlo methods }\end{array}$ & $\begin{array}{l}\text { Conveying } \\
\text { alternative } \\
\text { possible } \\
\text { answers } \\
\text { rather than a } \\
\text { single } \\
\text { conclusion, and } \\
\text { the } \\
\text { reasons for } \\
\text { them }\end{array}$ \\
\hline
\end{tabular}

Integrative tasks may vary from project to another and based on many research and activities' variables. However, there are certain tasks need to be defend in term of time, participants and skill needed. Table 12, gives a simple example of such tasks in agro-food based activities and the time to implement with involved stakeholders and needed skills. There are different ways of integrating/ classes that can be adapted based on the project and research nature. It is important to identify which integration way you can use and when. Table 13, gives some ways used in agro-food processing projects and research, however, there are more integration ways to learn about and to use.

Table 12. Example of some integrative tasks in agro-food research/projects-based activities.

\begin{tabular}{llll}
\hline Integrative tasks & Group & When & Skills are involved \\
\hline Agreement on research & Whole & Project design (at the & All skills in different disciplines \\
\hline
\end{tabular}




\begin{tabular}{|c|c|c|c|}
\hline or project goals & group & beginning) & \\
\hline $\begin{array}{l}\text { Common research } \\
\text { questions }\end{array}$ & $\begin{array}{l}\text { Whole } \\
\text { group }\end{array}$ & $\begin{array}{l}\text { Project design (at the } \\
\text { beginning) }\end{array}$ & All skills in different disciplines \\
\hline $\begin{array}{l}\text { Define specific output: } \\
\text { Feasibility studies }\end{array}$ & $\begin{array}{l}\text { Socio- } \\
\text { economy } \\
\text { group }\end{array}$ & $\begin{array}{l}\text { Project design (at the } \\
\text { beginning) }\end{array}$ & $\begin{array}{l}\text { Economy: Feasibility studies } \\
\text { and market analysis } \\
\text { Social Science: rural } \\
\text { development }\end{array}$ \\
\hline $\begin{array}{l}\text { Define specific output: } \\
\text { Food processing MSEs } \\
\text { (micro and small } \\
\text { enterprises) using modern } \\
\text { technology }\end{array}$ & $\begin{array}{l}\text { Food } \\
\text { processing } \\
\text { group }\end{array}$ & $\begin{array}{l}\text { Project design (at the } \\
\text { beginning) }\end{array}$ & $\begin{array}{l}\text { Engineering: Technology design } \\
\text { installation and maintenance } \\
\text { Food Sciences: Food } \\
\text { technology and safety/control } \\
\text { standards }\end{array}$ \\
\hline $\begin{array}{l}\text { New decision: Increasing } \\
\text { the eco-farming } \\
\text { activities }\end{array}$ & $\begin{array}{l}\text { Agri- } \\
\text { environment } \\
\text { group }\end{array}$ & At the middle & $\begin{array}{l}\text { Environmental Sciences: Land } \\
\text { and water resources protection. } \\
\text { Agriculture: Plots protection } \\
\text { and crop rotations design }\end{array}$ \\
\hline $\begin{array}{l}\text { Publications and result } \\
\text { dissemination }\end{array}$ & $\begin{array}{l}\text { Whole } \\
\text { group }\end{array}$ & At the end & All skills in different disciplines \\
\hline
\end{tabular}

Table 13. Ways of integrating/ classes used in agro-food processing projects and research.

\begin{tabular}{lll}
\hline $\begin{array}{l}\text { Ways of integrating/ } \\
\text { classes }\end{array}$ & Integrative task & Reasons to use \\
\hline $\begin{array}{l}\text { Dialogue method- } \\
\begin{array}{l}\text { Integrating judgments- } \\
\text { Consensus conference }\end{array}\end{array}$ & $\begin{array}{l}\text { Agreement between } \\
\text { project team and selected } \\
\text { stakeholders on research } \\
\text { or project goals }\end{array}$ & $\begin{array}{l}\text { Within "Egyptian context", it is better to use } \\
\text { consensus conference or similar dialogue } \\
\text { methods for project goals Agreement. }\end{array}$ \\
$\begin{array}{l}\text { Dialogue method- } \\
\text { Integrating judgments- } \\
\text { Delphi technique }\end{array}$ & $\begin{array}{l}\text { goals within } \\
\text { research/project team }\end{array}$ & $\begin{array}{l}\text { Working well with academic and reserchers and } \\
\text { another }\end{array}$ \\
$\begin{array}{l}\text { Dialogue method- } \\
\text { Integrating judgments- } \\
\text { nominal group } \\
\text { technique }\end{array}$ & $\begin{array}{l}\text { Food processing MSEs } \\
\text { (micro and small } \\
\text { enterprises) using modern } \\
\text { technology }\end{array}$ & $\begin{array}{l}\text { Working well with group of experts having } \\
\text { common knowledge and background. Nominal } \\
\text { group technique works well if Delphi technique } \\
\text { not effective as some stallholders (associations } \\
\text { representatives, local government } \\
\text { representatives) neither effectively use emails } \\
\text { nor properly answer the questionnaires. }\end{array}$ \\
& &
\end{tabular}




\begin{tabular}{lll}
\hline $\begin{array}{l}\text { Product-based/ } \\
\text { consensus conference }\end{array}$ & $\begin{array}{l}\text { e.g. creating food loss and } \\
\text { waste calculation } \\
\text { methodology }\end{array}$ & $\begin{array}{l}\text { There is plan to come up with one standard for } \\
\text { FLW calculation methodology for Egypt, this } \\
\text { way can help to integrate the process. }\end{array}$ \\
$\begin{array}{l}\text { Scenario planning } \\
\begin{array}{l}\text { Good to consider it } \\
\text { because of the pandemic } \\
\text { situation }\end{array}\end{array}$ & $\begin{array}{l}\text { dealing with the uncertainties e.g. because of } \\
\text { unexpected shortages that may happen in food } \\
\text { supply chain }\end{array}$ \\
\hline
\end{tabular}

A dynamic systems approach begins with defining problems dynamically, proceeds through modeling stages, then builds confidence in the model and its policy implications. Furthermore, Zwartkruis and Westhoek [32] stated that combining the analysis of different scientific approaches in agro-food sector: integrated assessment modelling, transition science research, and participative action research can provide better policy advice. Developing policy to ensure sustainable food security is a tremendous challenge that requires a comprehensive and integrated analytical approach. Multiple factors influence the course of human-environment interactions, which are further complicated by the presence of co-evolving causal forces. Understanding these dynamics requires viewing the food system as a whole. Social-ecological system approaches allow us to move away from looking at isolated events and their causes, and to begin looking at systems made up of interacting parts. Thus, conceptual models are needed to articulate crucial vulnerability and resilience factors to environmental and socioeconomic changes, postulating specific food and nutrition security issues as priority outcomes of food systems [33].

\subsection{Change}

It is important to decide which type of change we are going to achieve with implementing agrofood research/projects, the three types of changes are incremental change, reform or transformational change, Mostly, the running projects and research target reform, where we understand the system and to improve current knowledge of the dynamics of local food systems and to change market power for marginal farmers and food processors using sustainable practices with lowest possible environmental impact these type of change normally is being conducted based on responding to/and mitigation of specific economic and environmental. We have to look at different angles and dimensions when we target change and to consider that not all changes lead to good impact. Bammer [34] cleared that research findings enter a dynamic world not static one, where everything is changing all the time and researchers must negotiate a constantly changing environment to achieve the required impact from their research. This is true enough to observe that we have daily new methods, products, theories, etc. Table 14, illustrates some of the complexities trying to influence change and how we may avoid unintended consequences.

Table 14. Complexities trying to influence change [34].

\begin{tabular}{ll}
\hline Complexities & Solutions \\
\hline Stopping change from happening & $\begin{array}{l}\text { Requires work: maintaining soil quality, food quality, water } \\
\text { resources, etc.... require action to be taken for sustainability. }\end{array}$ \\
\hline
\end{tabular}




\section{Resistance to change \\ Change does not necessarily lead to improvement}

Success is in the eye of the beholder

Unpredictable outcomes
Changing "maintaining social continuity" concept

There is a need for constant monitoring to look for selfgenerating negative aspects

Change is seen to be good or bad depends on the perceptions of those making the assessment.

Scenario analysis to explore plausible future outcomes.

Understanding change will improve the ways we assess research impact, for example, there is always success by developing and introducing new farm machineries to save time and reduce cost, but there is a common problem and change that may happen because the economic effect of replacing labour by machines. So, providing alternative options and jobs for labour to avoid the negative economic impact should be considered with understating the nature and dimensions of change that will occur. Generally, in order to manage uncertainty in food systems, Reilly and Willenbockel [35] used scenario analysis in conjunction with food system models to explore plausible future outcomes, however, food system scenarios use a diversity of scenario types and modelling approaches determined by the purpose of the exercise and by technical, methodological and epistemological constraints.

\section{Conclusion}

To assess the sustainability of agro-food processing projects and research, we need to understand what might affect their processes in different implementing stages and how to utilize all possible solutions for better respond to the country' needs. We have to build a dynamic, shared knowledge banks to strengthen expertise in research integration and implementation. In order to achieve an effective analysis of agro-food processing research themes, comprehensive qualitative as well as quantitative analysis of problems investigations and required solutions is needed. Also, Understanding the ethical, legal and political issues that shape agri-food systems is also required. And no doubt, the benefits can be maximized if there is well-designed cooperation and alignment between the agricultural sector and other food processing and industries, retail and the water, consumers and end-users, and waste management sectors. Considering previous important concepts is the key success factor for collaboration between different teams and their themes of sciences in Agro-food processing. Agrofood processing projects and research are part of the global/Egyptian food systems that faces challenges related to food security, climate change, loss of biodiversity, and decrease of suitable land and water resources. Understanding climate change risks to food production is an important part of addressing these challenges. It requires consideration of complex interactions of bio-physical, economic, political and social factors at various scales. It is always important to remember that this type of knowledge need long time practice, engagement and understanding. There are no recipes for successfully implementing of specific interdisciplinary programs and models. The nature of success is as diverse as the goals and capabilities of our programs and there is no "one-size-fits-all" project' needs and requirements and to use each and every tool based on the context we are applying within. For greater impact, policy and decision makers and institutional work have more power to drive the real change by implementing such strategies through capacity-building, developing knowledge and skills, 
and changing the mind-set of the research and project communities.

\section{Acknowledgments}

The authors would like to thank the leaders and the organizers of 2020 Interdisciplinary Research Excellence Pilot Program. The programme is presented by the Egyptian Knowledge Bank (EKB) and Knowledge E (KnE); and in association with the Ministry of Higher Education and Scientific Research (MOHESR) and Integration and Implementation Sciences (i2S) at The Australian National University. The programme addresses multidisciplinary research challenges, complex real-world problems in Egypt. The strategic goals of the programme are to strengthen cross-disciplinary research collaboration, build new competencies, co-create knowledge, and produce tangible, collaborative work products that will offer immediate practical impact on sustainable development goals in the Egyptian context.

\section{Conflict of interest}

There is no conflict of interest.

\section{References}

1. Food and Agriculture Organization (2018) Climate Smart Agriculture Sourcebook. Food and Agriculture Organization of the United Nations (FAO). Available from: http://www.fao.org/climate-smart-agriculture-sourcebook/production-resources/module-b10value-chains/b10-overview/en/?type $=111$.

2. United States Department of Agriculture (2018) Ag and Food Sectors and the Economy. The United States Department of Agriculture (USDA). USDA ERS - Ag and Food Statistics. Available from: https://www.ers.usda.gov/data-products/ag-and-food-statistics-charting-theessentials/ag-and-food-sectors-and-the-economy/.

3. Legrand T (2018) Technical Report: Overviews of Food Systems and Agro-Industry, Value Chains, and Food Loss and Waste in the Countries of Eastern Europe and Central Asia. Food and Agriculture Organization of the United Nations, 1-73. Available from: http://www.fao.org/uploads/media/FAO_Food_Systems_Value_Chains_FLW_ECA.pdf.

4. Breisinger C, Raouf M, and Thurlow J, et al. (2019) Beyond the Business Case for Agricultural Value Chain Development: An economy wide approach applied to Egypt. Regional Program: Working Paper. International Food Policy Research Institute, IFPRI-Egypt, 1-27._Available from: https://www.ifpri.org/cdmref/p15738coll2/id/133192/filename/133403.pdf.

5. Katja B, Shahin J, Meyer T, et al. (2015) Building bridges, breaking barriers: The smart approach to distance between disciplines in research projects. European Commission, Directorate-General for Communications Networks, Content \& Technology. Final Report, 1126. Available from: https://op.europa.eu/o/opportal-service/downloadhandler?identifier $=0561 \mathrm{e} 5 \mathrm{fe}-66 \mathrm{a} 6-42 \mathrm{de}-8 \mathrm{~b} 6 \mathrm{f}-$ c3078eef3519\& format $=$ pdf\&language $=$ en $\&$ productionSystem $=$ cellar\&part $=$.

6. Bammer G, O'Rourke M, O'Connell D. et al.(2020) Expertise in research integration and implementation for tackling complex problems: when is it needed, where can it be found and 
how can it be strengthened?. Palgrave Commun 6: 1-16. https://doi.org/10.1057/s41599-0190380-0.

7. Academy of Scientific Research \& Technology (2020) The Academy of Scientific Research \& Technology (ASRT) information services, Ministry of Higher Education and Scientific Research, Egypt. Available from: http://www.asrt.sci.eg/ar/index.php/grants/jesor.

8. Horton P, Banwart SA, Brockington D, et al. (2017) An agenda for integrated system-wide interdisciplinary agri-food research. Food Sec 9: 195-210. https://doi.org/10.1007/s12571017-0648-4.

9. El Bilali H (2019) Research on agro-food sustainability transitions: A systematic review of research themes and an analysis of research gaps. Journal of Cleaner Production 221: 353-364. https://doi.org/10.1016/j.jclepro.2019.02.232.

10. Bennett LM, Gadlin H, Marchand C (2018) Collaboration and Team Science: A Field Guide. National Cancer Institute: Bethesda, Unites States of America. National Institutes of Health Publication, No. 18-7660: 1-139. Available from: https://www.cancer.gov/aboutnci/organization/crs/research-initiatives/team-science-field-guide/collaboration-team-scienceguide.pdf.

11. Currie M, Macleod CJA, De Bruin A, et al. (2016) Working Together For Better Outcomes: Good Practice For Interdisciplinary Researchers. Guidance Note, James Hutton Institute, Edinburgh, UK. Available from: https://www.researchgate.net/publication/295079312_Working together_for_better_outcome

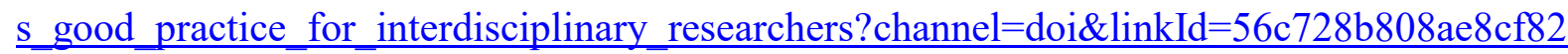
9049aae\&showFulltext $=$ true

12. Badham J, Bammer G (2017) Sharing mental models is critical for interdisciplinary collaboration. Blog post, Integration and Implementation Insights Research resources for understanding and acting on complex real-world problems (i2Insights). Available from: https://i2insights.org/2017/09/19/mental-models-and-interdisciplinarity/.

13. Easterling D (2016) five steps for managing diversity to create synergy. Blog post, Integration and Implementation Insights Research resources for understanding and acting on complex realworld problems (i2Insights). Available from: https://i2insights.org/2016/05/19/managingdiversity/.

14. European Network for Rural Development (2015) Improving stakeholder involvement. The European Network for Rural Development (ENRD), European Union, EU Rural Review No 19: 1-56. Available from: https://enrd.ec.europa.eu/sites/enrd/files/publi-enrd-rr-19-2015en.pdf.

15. Bammer G (2016) Two frameworks for scoping. Blog post, Integration and Implementation Insights Research resources for understanding and acting on complex real-world problems (i2Insights). Available from: https://i2insights.org/2016/08/16/scoping/.

16. Cabrera D, Cabrera L (2018) Frameworks for Transdisciplinary Research: Framework 4 (Four building blocks of systems thinking). GAIA - Ecological Perspectives for Science and Society 27: 200. https://doi.org/10.14512/gaia.27.2.3.

17. Durham E, Baker H, Smith M, et al. (2014) The BiodivERsA Stakeholder Engagement Handbook. BiodivERsA, The ERA-NET promoting European research on biodiversity, Paris (108 pp). Available from: http://www.biodiversa.org/702. 
18. Neef A, Neubert D (2011) Stakeholder participation in agricultural research projects: a conceptual framework for reflection and decision-making. Agric Hum Values 28:179-194. https://doi.org/10.1007/s10460-010-9272-z.

19. Njuki J, Kaaria S, Chitsike C, et al. (2006) Participatory Monitoring and Evaluation for Stakeholder Engagement, Assessment of Project Impacts, and for Institutional and Community Learning and Change. CIAT library, CGIAR: 1-24. Available from: http://ciatlibrary.ciat.cgiar.org/Articulos_CIAT/Njuki-rev.pdf.

20. Ivanov IT (2014) Stakeholder Engagement Plan. Final remarks. Krumovgrad Gold Project, Bulgaria. Available from: https://www.ebrd.com/documents/admin/krumovgrad-gold-mineproject-sep.pdf

21. Trudi VI, Baker C, Van Der Struijk LS, et al. (2010) Report on Stakeholder Analysis and Strategies for Stakeholder Engagement. Report no. D2.1_R3. WETwin project. Available from: http://www.wetwin.eu/downloads/D2-1.pdf.

22. Thoradeniya B, Maheshwari B (2017) Engaging stakeholders for water diplomacy: lessons for integrated water resources management, Water Diplomacy in Action: Contingent approaches to managing complex water problems, Ed. Shafiqul Islam and Kaveh Madani, Anthem press. Available

from:

https://Www.Researchgate.Net/Publication/315827893_Engaging_Stakeholders_For_Water

Diplomacy_Lessons_For_Integrated_Water_Resources_Management.

23. Boyce W, Percy H, Turner J, et al. (2016) Building co-innovation into your research proposal. Beyond Results from AgResearch and AgResearch Āta mātai, mātai whetū. Christchurch, New Zealand/Aotearoa. (Online). Available from: https://www.beyondresults.co.nz/assets/Documents/cbaa885462/Guide-to-Co-innovationFINAL-v2.pdf.

24. Vereijssen J, Srinivasan M S, Dirks S, et al. (2017) Addressing complex challenges using a coinnovation approach: Lessons from five case studies in the New Zealand primary sector. Outlook on Agriculture 46: 108-116. https://doi.org/10.1177\%2F0030727017712321.

25. Bammer G (2019) Key issues in co-creation with stakeholders when research problems are $\begin{array}{llllll}\text { complex. } & \text { Evidence } & \text { \& } & \text { Policy } & \text { 423-435. }\end{array}$ https://doi.org/10.1332/174426419X15532579188099.

26. Saragih HS, Tan JD (2018) Co-innovation: a review and conceptual framework. Int. J. Business Innovation and Research 17: 361-377. https://doi.org/10.1504/IJBIR.2018.095542.

27. Proparco (2019) Private Sector Development. Scaling Up the Development Impact of AgroIndustry. Proparco's magazine-31. Agence Française de Développement Group, Saint-Honoré, $75001 \quad$ Paris. Available from: https://issuu.com/objectifdeveloppement/docs/proparco psd31 agro industry uk.

28. Lam DPM, Martín-López B, Wiek A, et al. (2020) Scaling the impact of sustainability initiatives: a typology of amplification processes. Urban Transform 2: 1-24. https://doi.org/10.1186/s42854-020-00007-9.

29. Reed MS, Stringer LC, Fazey I, et al. (2014) Five principles for the practice of knowledge exchange in environmental management. Journal of Environmental Management 146: 337 345. https://doi.org/10.1016/j.jenvman.2014.07.021. 
30. United Nations Industrial Development Organization (2017) Integrated Agro-Industrial Parks in Egypt. Piloting the concept in Qalyoubia Governorate. United Nations Industrial Development Organization (UNIDO). Study by UNIDO/GTI and D'Appolonia. Available from: $\quad$ https://www.unido.org/sites/default/files/files/2019-05/AgroIndustrail\%20Parks\%20-\%20Qalyoubia\%20case\%201.pdf.

31. Zwartkruis J, Westhoek H (2017) Challenges and opportunities for change towards a more sustainable agro-food sector. Agro-food. European Union's Seventh Framework Programme for Research, Technological Development and Demonstration. PATHWAYS Final Policy Brief. Available from: https://www.pathwaysproject.eu/sites/default/files/PATHWAYS $\% 20$ final $\% 20$ policy $\% 20$ brief $\% 20$ agrofood.pdf.

32. Allen T, Prosperi P (2016) Modeling Sustainable Food Systems. Environmental Management 57: 956-997. https://link.springer.com/article/10.1007/s00267-016-0664-8.

33. Hamilton SH., ElSawah S, Joseph HAG, et al. (2015) Integrated assessment and modelling: Overview and synthesis of salient dimensions. Environmental Modelling \& Software 64: 215 229. https://doi.org/10.1016/j.envsoft.2014.12.005.

34. Bammer G (2015) Change! COMBINING ANALYTIC APPROACHES. Edited by Gabriele Bammer. Published by ANU Press, The Australian National University. Acton ACT 2601, Australia. Available from: http://dx.doi.org/10.22459/CCAASW.07.2015.

35. Reilly M, Willenbockel D (2010) Managing uncertainty: a review of food system scenario analysis and modelling. Food security: feeding the world in 2050. Edited by Charles H, Godfray J, John R, et al. Trans R Soc 365: 3049-3063. https://doi.org/10.1098/rstb.2010.0141. 